\title{
Review \\ PPAR Gamma: From Definition to Molecular Targets and Therapy of Lung Diseases
}

\author{
Márcia V. de Carvalho ${ }^{1,2,+}$, Cassiano F. Gonçalves-de-Albuquerque ${ }^{1,3,4, *,+}$ (D) and Adriana R. Silva ${ }^{1,2, *(D)}$ \\ 1 Laboratório de Imunofarmacologia, Instituto Oswaldo Cruz, Fundação Oswaldo Cruz (FIOCRUZ), \\ Rio de Janeiro 21040-900, Brazil; marciavcarvalho@gmail.com \\ 2 Programa de Pós-Graduação em Biologia Celular e Molecular, Instituto Oswaldo Cruz, Fundação Oswaldo \\ Cruz (FIOCRUZ), Rio de Janeiro 21040-900, Brazil \\ 3 Laboratório de Imunofarmacologia, Universidade Federal do Estado do Rio de Janeiro (UNIRIO), \\ Rio de Janeiro 20211-010, Brazil \\ 4 Programa de Pós-Graduação em Biologia Molecular e Celular, Universidade Federal do Estado do Rio de \\ Janeiro (UNIRIO), Rio de Janeiro 20211-010, Brazil \\ * Correspondence: cassiano.albuquerque@unirio.br (C.F.G.-d.-A.); arsilva71@gmail.com (A.R.S.) \\ + These authors contributed equally to this work.
}

Citation: Carvalho, M.V.d.;

Gonçalves-de-Albuquerque, C.F.;

Silva, A.R. PPAR Gamma: From Definition to Molecular Targets and Therapy of Lung Diseases. Int. J. Mol. Sci. 2021, 22, 805. https://dx.doi.org/ $10.3390 /$ ijms 22020805

Received: 21 August 2020 Accepted: 24 September 2020 Published: 15 January 2021

Publisher's Note: MDPI stays neutral with regard to jurisdictional clai$\mathrm{ms}$ in published maps and institutional affiliations.

Copyright: (C) 2021 by the authors. Licensee MDPI, Basel, Switzerland. This article is an open access article distributed under the terms and conditions of the Creative Commons Attribution (CC BY) license (https:// creativecommons.org/licenses/by/ $4.0 /)$.

\begin{abstract}
Peroxisome proliferator-activated receptors (PPARs) are members of the nuclear receptor superfamily that regulate the expression of genes related to lipid and glucose metabolism and inflammation. There are three members: PPAR $\alpha, \operatorname{PPAR} \beta$ or PPAR $\gamma$ PPAR $\gamma$ have several ligands. The natural agonists are omega 9, curcumin, eicosanoids and others. Among the synthetic ligands, we highlight the thiazolidinediones, clinically used as an antidiabetic. Many of these studies involve natural or synthetic products in different pathologies. The mechanisms that regulate PPAR $\gamma$ involve post-translational modifications, such as phosphorylation, sumoylation and ubiquitination, among others. It is known that anti-inflammatory mechanisms involve the inhibition of other transcription factors, such as nuclear factor $\mathrm{kB}(\mathrm{NF} \kappa \mathrm{B})$, signal transducer and activator of transcription (STAT) or activator protein 1 (AP-1), or intracellular signaling proteins such as mitogen-activated protein (MAP) kinases. PPAR $\gamma$ transrepresses other transcription factors and consequently inhibits gene expression of inflammatory mediators, known as biomarkers for morbidity and mortality, leading to control of the exacerbated inflammation that occurs, for instance, in lung injury/acute respiratory distress. Many studies have shown the therapeutic potentials of PPAR $\gamma$ on pulmonary diseases. Herein, we describe activities of the PPAR $\gamma$ as a modulator of inflammation, focusing on lung injury and including definition and mechanisms of regulation, biological effects and molecular targets, and its role in lung diseases caused by inflammatory stimuli, bacteria and virus, and molecularbased therapy.
\end{abstract}

Keywords: lung injury; acute respiratory distress; inflammation; PPAR $\gamma$; molecular targets

\section{Introduction}

Peroxisome proliferator-activated receptors (PPARs) are ligand-dependent transcription factors of the nuclear receptor superfamily that regulate the expression of specific target genes involved in energy and lipid metabolism, adipogenesis and inflammation. In mammals, the PPAR subfamily consists of three members: PPAR- $\alpha$, PPAR $-\beta / \delta$ and PPAR- $\gamma$ [1,2]. PPAR $\alpha$ (also called NR1C1) was initially identified as an orphan receptor activated by various peroxisome proliferators [3]. PPAR $\beta / \delta$ (NR1C2) and PPAR $\gamma$ (NR1C3) were subsequently cloned as related receptors that are activated by distinct peroxisome proliferators [4].

PPAR $\gamma$ has two major isoforms generated by alternative promoter usage, where PPAR $\gamma 1$ and PPAR $\gamma 2$ regulate differentially, for instance, the glucose and fatty acid metabolism and the mouse prostate benign epithelial cell differentiation [5]. 
PPAR $\gamma$ also regulate several metabolic diseases, such as obesity [6], diabetes [7], inflammatory diseases [8-11] and neuroinflammatory disease [12]. In this review, we focus on $\operatorname{PPAR} \gamma$, highlighting its attributions in pathophysiological processes, mainly those involving lung injury.

\section{Isoforms and Function of PPAR $\gamma$}

All PPAR $\gamma$ isoforms play an important role in adipocyte differentiation and glucose metabolism; however, their expression is different. The PPAR $\gamma 1$ isoform is expressed in nearly all cells, while PPAR $\gamma 2$ is limited to adipose tissue. Both forms of PPAR $\gamma 1$ and PPAR $\gamma 2$ are essential for the development of adipose tissue and the control of insulin sensitivity. Nevertheless, PPAR $\gamma 2$ is the isoform regulated in response to nutrient intake and obesity [13]. The PPAR $\gamma 1$ isoform is widely expressed in the colon, retina and hematopoietic cells and has also been detected at low levels in other organs, such as the spleen and heart [14].

Two isoforms of PPAR $\gamma, \gamma 1$ and $\gamma 2$, differently regulated the mouse prostatic epithelial differentiation. PPAR $\gamma 1$ caused decreased basal cell differentiation and increased tumorigenicity, and PPAR $\gamma 2$ increased basal cell differentiation. [5]. In other studies, it was also demonstrated that PPAR $\gamma 1$ has a role in oncogene and that PPAR $\gamma 2$ acts as a tumor suppressor in prostate cells [15].

\section{PPAR $\gamma$ Ligands and Overall Effects}

PPAR $\gamma$ is activated by several fatty acid metabolites, such as 15-deoxy-D12,14prostaglandin J2 [16], 9-hydroxyoctadecadienoic acid [17], nitrated fatty acids [18] and lysophosphatidic acid [19]. Other endogenous ligands such eicosapentaenoic acid (EPA) and docosahexaenoic acid (DHA) can bind to PPAR $\gamma$ by their metabolites and modulate the PPAR $\gamma$ expression $[20,21]$.

Compounds from the natural origin are also PPAR $\gamma$ ligands. Researchers identified a small molecular, astragaloside IV, from herbal extracts as a selective PPAR $\gamma$ natural agonist in nervous cells [22]. Another study showed that 6-shogaol attenuates the Gramnegative endotoxin lipopolysaccharide (LPS)-induced inflammation in cells by activating PPAR $\gamma$ [23].

Another group showed that an organosulfur garlic compound, alliin, improved gut inflammation through mitogen-activated kinase/nuclear factor kappa B/activator protein 1/signal transducers and activators of transcription 1 (MAPK-NFKB/AP-1/STAT-1) inactivation and PPAR $\gamma$ activation [24].

Vallée et al. demonstrated the effects of cannabidiol in interactions with the homologous wingless and int- 1 (wnt) $/ \beta$-catenin pathway and PPAR $\gamma$ on oxidative stress and neuroinflammation in Alzheimer's disease [25]. Studies have also shown that other natural PPAR $\gamma$ agonists can modulate intestinal [26,27] and lung inflammation [28].

Recently, our group demonstrated anti-inflammatory activity in both liver and adipose tissues from septic mice by Mediterranean diet components such as omega 9. Omega 9 is a PPAR $\gamma$ ligand. During sepsis, omega 9 restores PPAR $\gamma$ expression and controls exacerbated inflammation $[29,30]$. More ligands are presented throughout the text.

As well as certain PPAR $\gamma$ ligands, some natural products behave as PPAR $\gamma$ agonists and antagonists. The natural carotenoid astaxanthin found in seafood acts as a PPAR antagonist, inhibiting PPAR-transactivation activity in lipid-loaded hepatocytes [31].

PPAR $\gamma$ is activated by synthetic agonists, such as the thiazolidinedione (TZD) class of antidiabetic drugs, including pioglitazone and rosiglitazone. TZDs increase insulin sensitivity and improve glycemic control in patients with type 2 diabetes. Nevertheless, they induce adverse effects, such as bone loss, weight gain and fluid retention, which can exacerbate congestive heart failure [32]. In 1999, rosiglitazone was approved for therapeutic use in the United States [33]. Another compound of the thiazolidinediones class, pioglitazone, presented fewer side effects in patients compared to rosiglitazone [34]. 
Some years later, the increased risk of myocardial infarction and death in patients using those drugs was reported [35].

However, studies showed that pioglitazone attenuated cardiac mobilizations in alloxaninduced diabetic rabbits [36]. According to other studies, researchers have shown that pioglitazone reverses pulmonary hypertension and prevents heart failure via fatty acid oxidation [37].

The elucidation of the PPAR $\gamma$ molecular mechanisms will lead to the selective use in disease therapy [21].

\section{Mechanisms of Regulation of PPAR $\gamma$}

PPAR $\gamma$ is regulated by several post-translational modifications (PTM), including phosphorylation, small ubiquitin-like modifier (SUMO)ylation, ubiquitination, acetylation and glycosylation. Those PTM are nicely described by Brunmeir and Xu [38]. Most of the studies focus on mechanisms of regulation of PPAR $\gamma$ in cells involved in glucose metabolism. A few reports are discussing the importance of those mechanisms of PPAR $\gamma$ regulation in inflammatory cells. Among these PTM, we can highlight the following.

\subsection{Phosphorylation}

Phosphorylation regulates PPAR $\gamma$ activity, and PPAR $\gamma$, in turn, phosphorylates, for instance, MAP kinase, and negatively regulates MAP kinase activation.

Studies have shown that the anti-hypertensive drug telmisartan regulated PPAR $\gamma$ phosphorylation and its downstream gene expressions, promoted glucose uptake and acted as an overall insulin sensitizing agent in adipocytes [39]. PPAR $\gamma$ increased expression can be induced by some stimuli, such as peptidoglycan. That phenomenon is regulated by MAP kinase activation [40].

Researchers demonstrated an anti-inflammatory mechanism of galangin in microglia cells stimulated with lipopolysaccharide regulated by PPAR- $\gamma$ signaling, which will lead to inhibition of the phosphorylation of p38/extracellular signal-regulated kinase (ERK) MAP kinases and consequent inhibition of inflammatory cytokines via the NFKB pathway [41] (Figure 1B). Recently, a study showed an anti-inflammatory activity of a natural product via MAP kinase and PPAR $\gamma$ signaling pathways. Phelinnus linteus polysaccharide decreased cytokine expression, regulating PPAR $\gamma$ phosphorylation and MAP kinase pathway inhibition [42]. The plant component flavonoid hyperin is anti-inflammatory. It inhibited cytokine production in LPS-incubated macrophage through a PPAR $\gamma$-dependent mechanism involving inhibition of the ERK and p38 MAP kinases [43]. The topic "PPAR $\gamma$ interaction with other transcription factor and intracellular signaling proteins" in Section 5 goes further into the role of PPAR $\gamma$ modulating biological effects through phosphorylation.

\subsection{SUMOylation}

Ying and collaborators suggested that SUMOylation of PPAR $\gamma$ by an agonist downregulates chemokine expression through inhibition of $\mathrm{NFKB}$ in renal inflammation induced by LPS [44]. The SUMOylation pathway consists in three different proteases, SUMO E1, $\mathrm{E} 2$ and E3, that can alter the regulation transcription to target proteins, and the mechanism plays a crucial role in the regulation of cell cycle progression and processes of the tumorigenesis [45] (Figure 1A).

From 2005 onward, there are a few articles about PPAR $\gamma$ SUMOylation and ubiquitination in inflammatory cells. Some of them explore the role of SUMOylation in the anti-inflammatory properties of PPAR $\gamma[46-49]$.

\subsection{Ubiquitination}

Ubiquitination of PPAR $\gamma$ has only been studied in adipocytes, when the neural precursor cell expressed developmentally downregulated protein 4 (NEDD4), an E3 ubiquitin ligase, interacts with the hinge and ligand binding domains of PPAR $\gamma$. NEDD4 increases PPAR $\gamma$ stability through the inhibition of its proteasomal degradation [50], and another 
study showed that the E3 ubiquitin ligase tripartite motif containing 23 (TRIM23) regulates adipocyte differentiation via stabilization of the PPAR $\gamma$ [51] (Figure 1C).

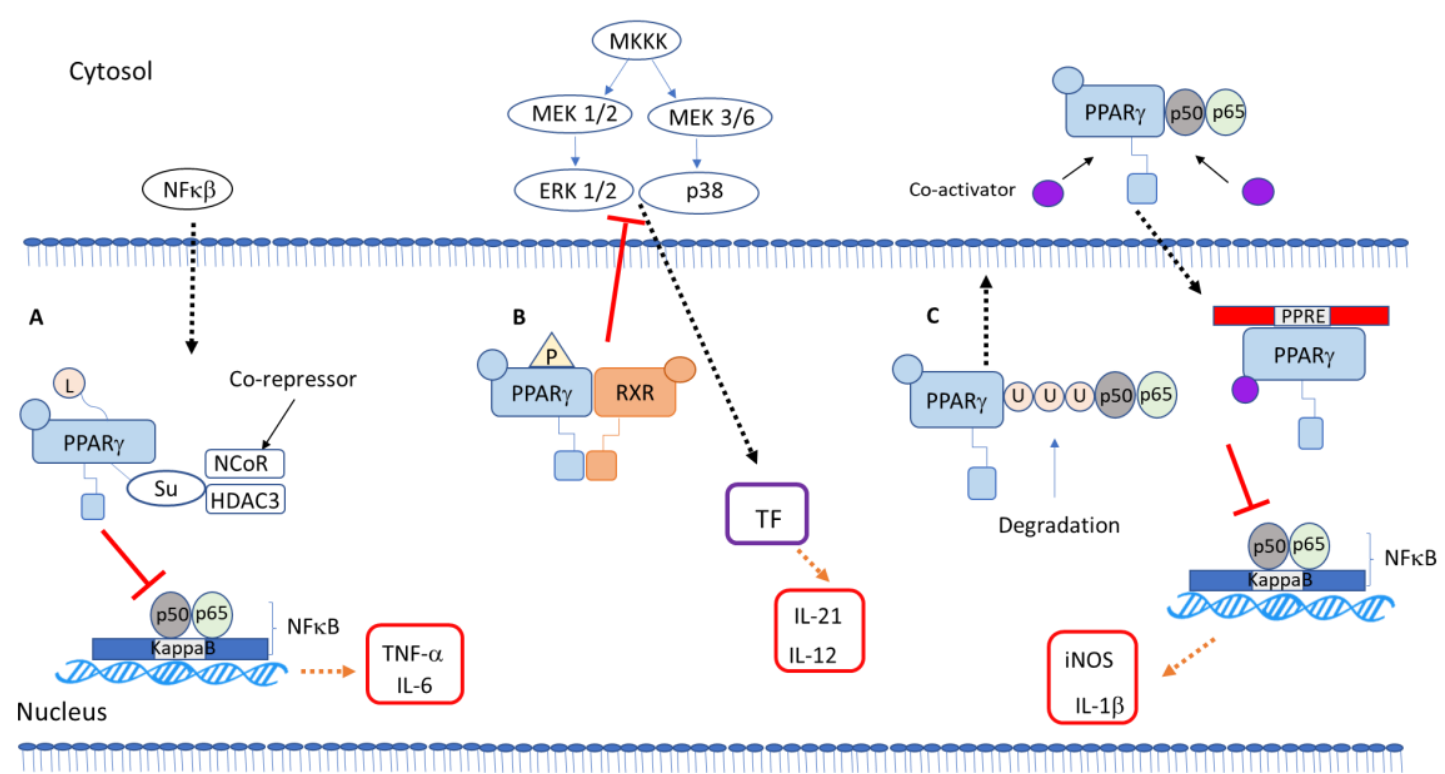

Figure 1. Molecular regulatory mechanisms of PPAR $\gamma$. (A) A ligand-dependent transrepression. Binding to PPAR $\gamma$ ligand leads to SUMOylation of PPAR $\gamma$, which stabilizes the co-repressor, leading to blockade of NFKB target gene expression. (B) Non-genomic role of PPAR $\gamma$. PPAR $\gamma$ phosphorylates MAP kinase, leading to inhibition of transcription factor (TF) binding. (C) Transrepression. ubiquitination of PPAR $\gamma$ increases its stability, and it can also inhibit NFKB target genes. $\operatorname{PPAR} \gamma$ (peroxisome proliferator-activated receptor $\gamma$ ), small ubiquitin-like modifier (SUMO)ylation, NFkB (nuclear factor kappa B).

\subsection{Acetylation}

Researchers identified five acetylated lysine residues at positions K98, K107, K218, K268 and K293, of which two (K268ac and K293ac) could be blocked by administration of the TZD rosiglitazone (agonist PPAR $\gamma$ ), or by activation of the nicotinamide adenine dinucleotide (NAD_ (-dependent deacetylase sirtuin-1 (SIRT1) deacetylase. In their study, they showed that SIRT1 promotes a beneficial metabolic effect through interaction with PPAR $\gamma$, leading to insulin sensitization, and implied a therapeutic potential of TZD and SIRT1 agonist combination therapy for obesity [52].

\subsection{Glycosylation}

The $\beta$-O-linked $\mathrm{N}$-acetylglucosamine (O-GlcNAc) modification, a post-translational modification on various nuclear and cytoplasmic proteins, is involved in the regulation of protein function. Studies showed that PPAR $\gamma$ is modified by O-GlcNAc in 3T3-L1 adipocytes. In these cells, an increase in O-GlcNAc modification by our inhibitor reduced PPAR $\gamma$ transcriptional activity and terminal adipocyte differentiation. The results suggested that the O-GlcNAc state of PPAR $\gamma$ influences its transcriptional activity, and it is involved in adipocyte differentiation [53].

\section{PPAR $\gamma$-Dependent Anti-Inflammatory Mechanisms}

Inflammation is the mechanism of human diseases, displaying the five classic inflammatory signs: redness, swelling, heat, pain and subsequent loss of organ function. The inflammation can be distinguishing the following types of inflammation: microbial, autoimmune, allergic, metabolic and physical inflammation, depending on the nature of the irritating cause. 
In one inflammatory process, many cells and mediators participate after some inflammatory injury. Some non-immune cells, like skin keratinocytes, mucosal epithelial cells and vascular endothelial cells, act as a first barrier and serve as a sentinel for the exogenous and endogenous causes of inflammation [54]. These cells, together with polymorphonuclear leucocytes (neutrophils, eosinophils, basophils) and the strategically positioned macrophages, dendritic cells, Natural Killer (NK) cells, among others, alert the immune system to the presence of inflammation-causing irritants and modulate the inflammatory response [55,56]. These innate immunity effectors establish a tight communication with $\mathrm{B}$ and $\mathrm{T}$ cells, constituting adaptive immunity. The effectors provide the signaling relays in inflammation caused by allergies, autoimmune diseases and microbes.

Inflammation as the body's response to an injury at first would be beneficial, because there would be a mobilization of the innate and adaptive immune system, and this would help to contain the cause of the inflammation, and consequently, the healing of damaged tissues. The "good" side of inflammation [57] will depend on the activity of endogenous suppressors of the inflammatory signaling pathways. Nevertheless, when these physiological suppressors do not work correctly, acute or chronic uncontrolled inflammation can lead to apoptosis, necrosis, fibrosis and ultimately, organ dysfunction at the end of the process [58].

During the process, the adaptative and innate cells respond to proinflammatory injury, producing intracellular and extracellular mediators such as cytokines, chemokines and hematopoietic/vascular growth receptors, while displaying their intrinsic factors. The inflammatory response is perpetuated by self-regulatory feeding loops. Also, intercellular and intracellular inflammatory responses are mediated by cell adhesion molecules, complementary proteins and signal transducers $[59,60]$. Resolution is also mediated by a wide variety of signals, including cytokines and chemokines, among others [61].

\section{PPAR $\gamma$ Interaction with Other Transcription Factors and Intracellular Signaling Proteins}

The nucleus of the cell is the receptor, processor and propagator of signals that transmit, maintain and extinguish inflammation. At the core, there is a regulatory network that interacts with transcription factors. They regulate genes by binding to their promoters and enhancers, determining the gene profiles of each cell $[62,63]$.

Transcription factors are regulators mobilized to initiate a profound reprogramming of the genome in response to proinflammatory insults. Preventing transcription factors NFKB, AP-1 and STAT1 from going to the nucleus has established their role in inflammation. The pathways have an essential role in the inflammatory process [64].

Many studies show the participation of another nuclear transcription factor, the $\operatorname{PPAR} \gamma$, in inflammatory processes. This factor can negatively modulate other transcription factors in transrepression mechanisms [38].

Studies have already demonstrated that PPAR $\gamma$ has anti-inflammatory effects through innate immune signaling by $\mathrm{NFKB}$, particularly in macrophages. These cells are furthermore capable of producing several PPAR $\gamma$ ligands, which can potentiate the anti-inflammatory pro-resolving actions of this receptor on other cells.

Researchers evaluated the involvement of STAT6 and PPAR- $\gamma$ signaling during acute schistosomiasis. In this model, the CX3CR-1 chemokine-deficient macrophage enhanced STAT6, leading to the PPAR $\gamma$ signaling to promote macrophages towards M2 polarization, which is an anti-inflammatory and pro-resolutive profile [65].

Another study showed that in an atherosclerosis process, the macrophage molecular signaling and inflammatory responses during ingestion of lipoproteins are modulated by complement protein $1 \mathrm{q}(\mathrm{C} 1 \mathrm{q})$, where this protein suppressed JAK-STAT pathway activation and increased transcriptional activation of PPAR $\gamma$, coherent as an M2-like polarized response [66].

Geng et al. reported a model of Alzheimer's disease, showing that the inhibition of miR-128 reduced amyloid- $\beta$-mediated cytotoxicity by upregulation of PPAR $\gamma$ and NFKB inactivation in mice neuronal cells and Neuro2a lineage cells [67]. 
Researchers also showed that suppressing NFKB (p65) protein synthesis and increasing PPAR $\gamma$ gene and protein expression helped magnesium administration to decrease blood glucose levels in diabetic animals [68].

Recently, one group showed that telmisartan, besides its role as an anti-hypertensive drug, has effects against oxidative stress, apoptosis, inflammatory responses and epithelialmesenchymal transition (ETM). Telmisartan improved oxalate and calcium oxalate crystalinduced EMT by exerting an antioxidant effect through the PPAR $\gamma$-AKT/STAT3/p38 MAP kinase-Snail signaling pathway. Therefore, telmisartan can block EMT progression and is a potential therapeutic agent for preventing and treating a renal pathology or its recurrence [69].

PPAR $\gamma$ agonist could alleviate intraperitoneal adhesion by regulating macrophage polarization and the suppressor of cytokine signaling proteins (SOCS)/JAK2/STAT/PPAR $\gamma$ signaling pathway [70].

Those reports relating the anti-inflammatory role of PPAR $\gamma$ to the inhibition of other transcription factor activity describe PPAR $\gamma$ 's ability to cause transrepression. The effect of PPAR $\gamma$ on MAP kinases is related to non-genomic activity of PPAR $\gamma$ (Figure 1).

The other anti-inflammatory mechanisms of PPAR $\gamma$ include the prevention of clearance of complexes after SUMOylation, repressing the transcription of inflammatory mediator genes. It involves SUMOylation of the PPAR $\gamma$-ligand binding domain, keeping the NR co-repressor/histone desacetilase 3 (NCor/HDAC3) complex on the promoter, repressing the transcription of inflammatory genes [46,47]. Instead of acting as a transcriptional activator, SUMOylated PPAR $\gamma$ represses transcription [48,49] (Figure 1).

\section{Pharmacologic and Therapeutic Potentials of PPAR $\gamma$ Ligands}

PPAR $\gamma$ agonists have different effects on a variety of diseases. For instance, the 15d-PGJ2 inhibited tumor progression in vivo [71] and induced apoptosis in tumor cells, suggesting the use of this agonist as an anticancer agent [72]. The PPAR $\gamma$ ligand VSP-77, in a mice model, reduced fasting glucose and insulin levels [73], illustrating its known role as an antidiabetic. Also, PPAR $\gamma$ agonists were linked to reduced chronic obstructive pulmonary disease (COPD) exacerbation rate in diabetic patients, showing PPAR $\gamma^{\prime}$ s role in lung diseases [74].

Natural compounds may exert their effect through PPAR, as discussed earlier. Curcumin, a spice derived from the rhizome of Curcuma longa Linn [75,76], and magnolol, a natural compound isolated from Magnolia officinalis [77,78], showed anti-inflammatory properties.

The compounds targeting PPAR $\gamma$ have their anti-inflammatory activity by inhibiting inflammatory cytokines and activating immune cells. Thus, PPAR $\gamma$ can become a potential therapeutic target for inflammatory bowel diseases, for instance, because PPAR $\gamma$ is highly expressed in the gut [79]. In an animal model, PPAR $\gamma$ reduced hepatic ischemiareperfusion injury (IRI) and decrease the pro-inflammatory population of Kupffer cells altering macrophage polarization [80]. The family with sequence similarity $3 \mathrm{~A}$ (FAM3A), a direct target gene of PPAR $\gamma$, mediates PPAR $\gamma$ protective effects in liver IRI [81]. PPAR $\gamma$ deletion enlarged infarct size, promoted neuron apoptosis and aggravated the ER stress [82]. Likewise, pioglitazone treatment reduced hepatic inflammation and oxidative stress and improved liver function in renal IRI [83]. Thus, $\operatorname{PPAR} \gamma$ seems to have a critical role in IRI in the liver, kidney and brain.

A synthetic PPAR $\gamma$ agonist showed a potent anti-inflammatory action modulating cytokine overproduction, proving to be a good candidate for COVID-19 infections [84].

Herein, we further discuss the role of synthetic or natural PPAR agonists in lung inflammatory diseases and bacterial and viral infections, evidencing the potential therapeutic role of those compounds in diverse pathologies involving lung injury. 


\subsection{PPAR $\gamma$ Role in Lung Inflammatory Diseases}

IRI can occur with pulmonary thromboembolectomy and lung transplantation, and is characterized by lung inflammation with edema [85]. The use of either rosiglitazone or troglitazone inhibited the IR-induced increase of pro-inflammatory cytokines and neutrophil accumulation in the lung [86].

PPAR $\gamma^{\prime}$ s role in cancer has excelled. PPAR $\gamma$ hampered tumor development and progression, and controlled the tumor microenvironment, ameliorating tumor growth and metastasis [87]. Treatment with PPAR $\gamma$ agonist and radiotherapy enhanced the effectiveness of tumor control and dampened metastasis [88]. The cyclooxygenase (COX) metabolite prostacyclin acted through PPAR $\gamma$, promoting anticancer signaling [89]. PPAR $\gamma$ activation transrepressed the NFkB pathway, blocking cell proliferation, differentiation and apoptosis in non-small cell lung carcinoma [90]. PPAR $\gamma$ agonists can be used as monotherapy in lung cancer, or associated with cytotoxic agents [91].

PPAR $\gamma$ has been considered a molecular target for effective asthma therapy [92]. $\operatorname{PPAR} \gamma$ negatively regulated the production of mucin and inflammatory mediators by repressing gene expression in primary human bronchial epithelial cells during allergic airway inflammation [93]. Korean red ginseng and Salvia plebeia R.Br. alleviated ovalbumininduced asthma in mice in a fashion dependent on the upregulation of the PPAR $\gamma$ gene and blocking protein kinase B (PKB or Akt) and phosphatase and tensin homolog (PTEN) phosphorylation [94]. The multifaceted anti-inflammatory effects in lung cells during allergic airway diseases [92] point to potential as an adjuvant therapy.

In lung inflammatory disorders, reactive oxygen species (ROS) is a protagonist in diseases such as chronic obstructive pulmonary disease (COPD) and acute respiratory distress syndrome (ARDS) [95]. Cytokines with pro-inflammatory activities are considered biomarkers, predictors of morbidity and mortality during ARDS [96]. LPS induces ROS production and adhesion molecules' expression. Higher levels of intercellular adhesion molecule-1 (ICAM-1) and vascular cell adhesion molecule 1 (VCAM-1) expression promote the recruitment of leukocytes to the lung, leading to the production of proinflammatory cytokines in the tissue [97]. Curcumin, the dietary polyphenol isolated from the rhizome of turmeric, inhibited NF- $\mathrm{KB}$ in COPD, decreasing inflammatory mediator production. Curcumin inhibited NF- $\mathrm{KB}$ and upregulated PPAR $\gamma$ activation, ameliorating cigarette smoke extract-induced inflammation in vivo and in vitro [98]. The activation of PPAR $\gamma$ may be an effective therapeutic approach in COPD, as it reduced cigarette smoke-induced inflammation and decreased the magnitude of bacterial infection-caused exacerbations [99].

Cystic fibrosis is an inherited disease with mutations on the cystic fibrosis transmembrane conductance regulator (CFTR) gene [100]. A deletion of phenylalanine 508 (F508) affects a high percentage of patients and results in inflammation and other alterations [101,102]. Cystic fibrosis epithelial cells present lower FOXO1 expression [103] and deficiency in PPAR $\gamma$ [104]. Myriocin inhibits ceramide synthesis, reducing inflammation and improving response against infections $[105,106]$. Transcription factor EB (TFEB) promotes the activation of PPAR and the FOXO family of transcriptional factors involved in lipid homeostasis and inflammatory responses [107]. Treatment with myriocin stimulates nuclear translocation of PPAR $\gamma$ and FOXO1A on F508-CFTR bronchial epithelial cell line IB3-1 cells [108].

LPS-induced endotoxemic shock involves dysregulated inflammation that injures the lungs, and it is often fatal. Endothelial cell PPAR $\gamma$ knockout worsened LPS-induced pulmonary inflammation and injury. There was infiltration of inflammatory cells, edema and ROS and pro-inflammatory cytokine production, with the upregulation of TLR4 expression and activation in lung tissue [109].

HO-1 (heme oxygenase-1), an antioxidant enzyme, is induced by PPAR ligands. PPAR activation and HO-1 can exert therapeutic effects on lung inflammation [110,111]. PPAR $\gamma$ directly regulates HO-1 transcription, impacting inflammation, ROS production and apoptosis $[112,113]$. The upregulation of $\mathrm{HO}-1$ by PPAR $\gamma$ agonists also inhibits pulmonary cell proliferation and remodeling [114]. HO-1 induction by rosiglitazone via the protein 
kinase $\mathrm{C} \alpha(\mathrm{PKC}) \alpha /$ adenosine monophosphate-activated protein kinase (AMPK) / p38 MAPK/SIRT1/PPAR $\gamma$ pathway suppresses LPS-mediated pulmonary inflammation. Rosiglitazone induces HO-1 expression via either NOX/ROS/c-Src/Pyk2/Akt-dependent Nrf2 activation or PPAR $\gamma$ in human pulmonary alveolar epithelial cells (HPAEpiCs) and suppresses LPS-mediated inflammatory responses, suggesting that PPAR $\gamma$ agonists may be useful for protection against pulmonary inflammation [115]. Upregulation of HO-1 protected against the inflammatory responses triggered by LPS, at least in part, through attenuation of NF-kB [116].

Natural products that bind to PPAR may have a critical role in lung inflammatory response. Wogonin, a flavonoid-like chemical compound found in Scutellaria baicalensis, inhibited the production of numerous inflammatory cytokines, including TNF $\alpha$, IL-1 $\beta$ and IL-6, in the broncoalveolar fluid (BALF) and lung tissues after LPS challenge. The PPAR $\gamma$ inhibitor GW9662 reversed these effects. Wogonin activated PPAR $\gamma$, which decreased NFKB translocation to the nucleus and binding to DNA in vivo and in vitro [117]. Engeletin (dihydrokaempferol 3-rhamnoside) is a flavanonol glycoside [118]. It can be found in white grapes and white wine. Engeletin activates PPAR- $\gamma$ and presented protective and therapeutic effects against LPS-induced lung injury [119]. Smiglaside A, a phenylpropanoid glycoside isolated from the traditional Chinese medicinal herb Smilax riparia, foster macrophage polarization to an anti-inflammatory M2 phenotype via the AMPK-PPAR $\gamma$ signaling pathway [120]

Endogenous products such as resolvin D1 may also bind to PPAR. Animals who received resolvin D1 stimulated with LPS had lower leukocyte counts and TNF- $\alpha$ and IL-6 levels in BALF compared to the LPS group. Resolvin D1 activated PPAR $\gamma$ and attenuated lung inflammation of LPS-induced acute lung by suppressing NFKB activation [121].

Mesenchymal stem cells are multi-potent non-hematopoietic stem cells residing in most tissues, including the lung [122]. The main beneficial effects reside in the released extracellular vesicles with anti-inflammatory properties. The extracellular vesicles derived from lung mesenchymal stem cells upregulated the PPAR $\gamma$ axis, showing anti-inflammatory and antioxidant effects [123].

Interestingly, recent reports discussed the crosstalk between PPAR pathways with glucocorticoids and adenosine A2A receptor (A2AR). The establishment of ER-Hoxb8immortalized bone marrow-derived macrophages from Pparg ${ }^{\mathrm{fl} / \mathrm{fl}}$ and LysM-Cre Ppargfl/fl mice allowed the authors to show the effect of glucocorticoid on PPAR $\gamma$ knockout macrophages. Interestingly, glucocorticoid induces increased recruitment of PPAR $\gamma \mathrm{KO}$, but not PPAR $\gamma$ wildtype macrophages to the site of inflammation. It is a molecular link between glucocorticoids and PPAR $\gamma$, showing that PPAR $\gamma$ modulates glucocorticoid-induced migration in macrophages [124]. The activation of PPAR $\gamma[125,126]$ and adenosine A2A receptor (A2AR) $[127,128]$ have anti-inflammatory properties in acute lung injury. The A2AR stimulated PPAR $\gamma$ expression via protein kinase A(PKA)- cyclic adenosine monophosphate (cAMP)-response element binding protein (CREB) signaling. PPAR $\gamma$ and A2AR could upregulate the mRNA and protein expressions of each other, generating a positive feedback loop between both increasing their anti-inflammatory effect and reducing lung damages in lung injury [129].

Adipocytokines, such as adiponectin and leptin, are mediators produced mainly by adipocytes and can be regulated by PPAR $\gamma$ [11]. Leptin is a primarily pro-inflammatory adipokine that induced the production of Th1 cytokines (TNF- $\alpha$, IL-6 and IL-12) [130-132] and blocked the production of Th2 cytokines (IL-4, IL-5 and IL-10) [133,134]. The leptin receptor is expressed by human lung cells [135-137]. Leptin decreases the expression of PPAR $\gamma$ in rat adipose and liver tissues [138]. Leptin also counteracts PPAR $\gamma$ antiinflammatory action, which may impact lung inflammatory status during different pulmonary diseases. Adiponectin is predominantly an anti-inflammatory adipokine that inhibits pro-inflammatory cytokines (TNF, IL-6) [139] and induces anti-inflammatory cytokines (IL-10) [140,141]. Adiponectin, adiponectin-activated PPARs and PPAR-induced 
adiponectin attenuate inflammation [142]. Thus, the balanced release of these adipocytokines driven by PPAR $\gamma$ activation may link adipose tissue to lung pathology [137].

\subsection{PPAR $\gamma^{\prime}$ s Role in Bacterial Lung Infection}

The alveolar macrophages are key players in pulmonary antimicrobial defense and lung homeostasis [143-146]. The PPAR $\gamma$ is critical in the alveolar macrophage development and function [147-150]. The absence of PPAR $\gamma$ in alveolar macrophages boosted Th1-biased inflammation and defective resolution of inflammation [151].

Bacterial infection in the lung induces an inflammatory response that leads to the destruction of the invading pathogen. Nevertheless, the persistence of the inflammation may result in a condition termed non-resolving pneumonia [152]. Bacterial pneumonia is still responsible for a massive number of casualties worldwide [153]. Alveolar macrophages and neutrophils are the major cell types that kill internalized lung bacteria [154]. Mice infected with Klebsiella pneumoniae develop lung injury with an accumulation of cardiolipin, the main lipid of the inner mitochondrial membrane. High concentrations of cardiolipin have been detected in the lung fluid of patients with pneumonia [155]. Cardiolipin induces SUMOylation of PPAR $\gamma$ at K107, which is distinct from the SUMOylation rosiglitazone [47]. Cardiolipin-induced SUMOylation inhibits IL-10 production by lung CD11b pLy6GintLy6CloF4/80 p cells because of the recruitment of a repressive nuclear receptor corepressor (NCOR) / histone deacetylase 3 (HDAC3) complex to the IL-10 promoter, ending in persistent inflammation during pneumonia [156].

The pathogenic $P$. aeruginosa has diverse immune system evading mechanisms, including the production of virulence factors and biofilm formation. PPAR $\gamma$ agonists play a pivotal role in the host response to virulent $P$. aeruginosa [157]. Quorum sensing is a mechanism wherein the bacteria secrete small molecules, such as N-(3-oxo-dodecanoyl)1-homoserine lactone (3O-C12-HSL), that promote biofilm formation and interbacterial communication [158]. Quorum sensing genes in P. aeruginosa (strain PAO1) and 3O-C12HSL attenuate PPAR $\gamma$ expression in bronchial epithelial cells, with loss of barrier integrity and decreased junctional proteins (occludin, claudin-4), which is restored by PPAR $\gamma$ agonists [157]. So, the use of PPAR $\gamma$ agonists can serve as an adjuvant in treating resistant $P$. aeruginosa infections.

The absence of PPAR $\gamma$ in lung macrophages reduces the growth of virulent $M y-$ cobacterium tuberculosis, enhances proinflammatory cytokines and reduces granulomatous infiltration-PPAR $\gamma$ activation - which downregulates macrophage proinflammatory responses and enables Mycobacterium tuberculosis growth [159]. A murine model of multiwall carbon nanotube (MWCNT) elicited chronic granulomatous disease, which resembles human sarcoidosis pathology, including alveolar macrophage PPAR $\gamma$ deficiency. PPAR $\gamma$ deficiency promotes pulmonary mycobacterial early secreted antigenic target protein 6 (ESAT-6) retention, exacerbates macrophage responses to MWCNT + ESAT-6 and intensifies pulmonary fibrosis [160]. The cells overexpressing CYP1A1 infected with Micoplasma hyopneumoniae led to an increase in PPAR $\gamma$ expression, resulting in lower production of IL-1b, IL-6, IL-8 and TNF- $\alpha$ in pigs [116].

Sepsis is a systemic inflammatory syndrome in response to an infection [161]. Pioglitazone decreased inflammatory response in polymicrobial sepsis targeting the NFkB pathway, which reduced pro-inflammatory cytokines levels [162]. Sepsis causes changes in PPAR $\gamma$ expression and activation [29], in part because of phosphorylation of PPAR $\gamma$ by ERK1/2. ERK1/2 inhibition reversed PPAR $\gamma$ phosphorylation, ameliorating lung injury [163].

Triggering receptor expressed on myeloid cells 2 (TREM)-2 macrophages [164] negatively regulate toll-like receptor (TLR)-mediated responses and enhance phagocytosis. TREM-2 enhances bacterial elimination and improves survival in a sepsis model [165]. Trem- $2^{-/-}$mice infected with S. pneumoniae exhibited an augmented bacterial clearance from the lungs. The increased levels of $\mathrm{C} 1 \mathrm{q}$ were crucial for enhanced bacteria phagocytosis in a mechanism dependent on PPAR $\gamma$ activity [166]. 


\subsection{PPAR $\gamma$ Role in Viral Lung Infection}

The PPAR $\gamma$ agonists TZDs have ameliorating effects on severe viral pneumonia. Also, diet ligands of PPAR $\gamma$, like curcuma, lemongrass and pomegranate, have anti-inflammatory properties through PPAR $\gamma$ activation, acting as immunomodulators regulating cytokine levels [84]. In this regard, both natural and synthetic PPAR- $\gamma$ ligands treatment declined host morbidity and mortality during influenza A virus infection [78,167-170]. PPAR $\gamma$ expression was downregulated in resident macrophages during influenza A virus infection. A phytohormone abscisic acid binds to the G-protein coupled receptor lanthionine synthetase component C-like 2, increasing cAMP levels [171]. The abscisic acid modulates immune and inflammatory responses in mouse models of colitis and obesity [172]. Also, abscisic acid improves influenza virus-induced pathology by activating PPAR $\gamma$ in lung immune cells [173]. The PPAR $\gamma$ activation by the 15d-PGJ2 protects mice against influenza virus infection with reduced lung cytokine production [169]. The myeloid PPAR $\gamma$ expression in alveolar macrophages is critical for modulating pulmonary inflammation, the development of host diseases and the recovery of tissue homeostasis following respiratory viral infections [174].

The genetic-induced obese $(\mathrm{db} / \mathrm{db})$ mice were more susceptible to viral infection with higher viral replication, higher inflammatory response and damaged lung repair after influenza infection, with an increased mortality rate. PPAR $\gamma$ was downregulated in the lung macrophages of $\mathrm{db} / \mathrm{db}$ mice after influenza infection. Strikingly, the treatment with 15d-PGJ2 protected the $\mathrm{db} / \mathrm{db}$ mice after influenza infection [175]. Thus, treatments with $\operatorname{PPAR} \gamma$ agonists may be a potential candidate to treat influenza infection in obese patients.

The coronavirus disease 2019 (COVID-19) and type 2 diabetes are two pandemic diseases with enormous health and economic costs. Some COVID-19 patients may evolve to severe pneumonia with a high fatality rate, especially in patients with chronic conditions, such as diabetes and cardiovascular disease. Severe acute respiratory syndrome coronavirus (SARS-CoV-2) binds to the angiotensin-converting enzyme 2 (ACE2). In an obesity animal model, pioglitazone increased the expression of ACE2 in liver, adipose tissue and skeletal muscle [176]. Rosiglitazone also induced an increase in ACE2 expression [177]. Those drugs are broadly adopted in type-2 diabetes [178]. Therefore, the use of this PPAR $\gamma$ agonist may be used with caution during the COVID-19 pandemic.

Using data from the National Health and Nutrition Examination Survey (NHANES) between 1988-1994 and 1999-2010, it was shown that influenza/pneumonia mortality was associated with the medication. Patients taking rosiglitazone had an increased risk of mortality from influenza/pneumonia. Although most influenza infections do not represent a health burden, secondary bacterial infection results in high rates of mortality and morbidity. Viral infection, such as influenza, predisposes the lung to secondary bacterial infection by dysregulation of the host immune response [179-182]. Communityacquired methicillin-resistant Staphylococcus aureus (MRSA) represents a severe life threat during influenza-associated secondary bacterial infection [183,184]. Rosiglitazone has an anti-inflammatory effect during acute pulmonary inflammation [185]. Rosiglitazone treatment compromised bacterial clearance during influenza-bacterial super-infection, thus worsening the outcome of influenza-associated pneumonia [186]. The use of natural or synthetic anti-inflammatory compounds must be used with caution during viral infection so as to prevent potential future patients' immune response derangement and increased risk of infections.

A simplified scheme of PPAR $\gamma$ actions in the lung is shown in Figure 2.

After a lung injury, an inflammatory process is observed, with an increase in proinflammatory cytokines and edema formation. After binding to its agonist, PPAR $\gamma$ inhibits transcriptional factor, leading to a decrease in proinflammatory mediators and to early resolution of the inflammation. 


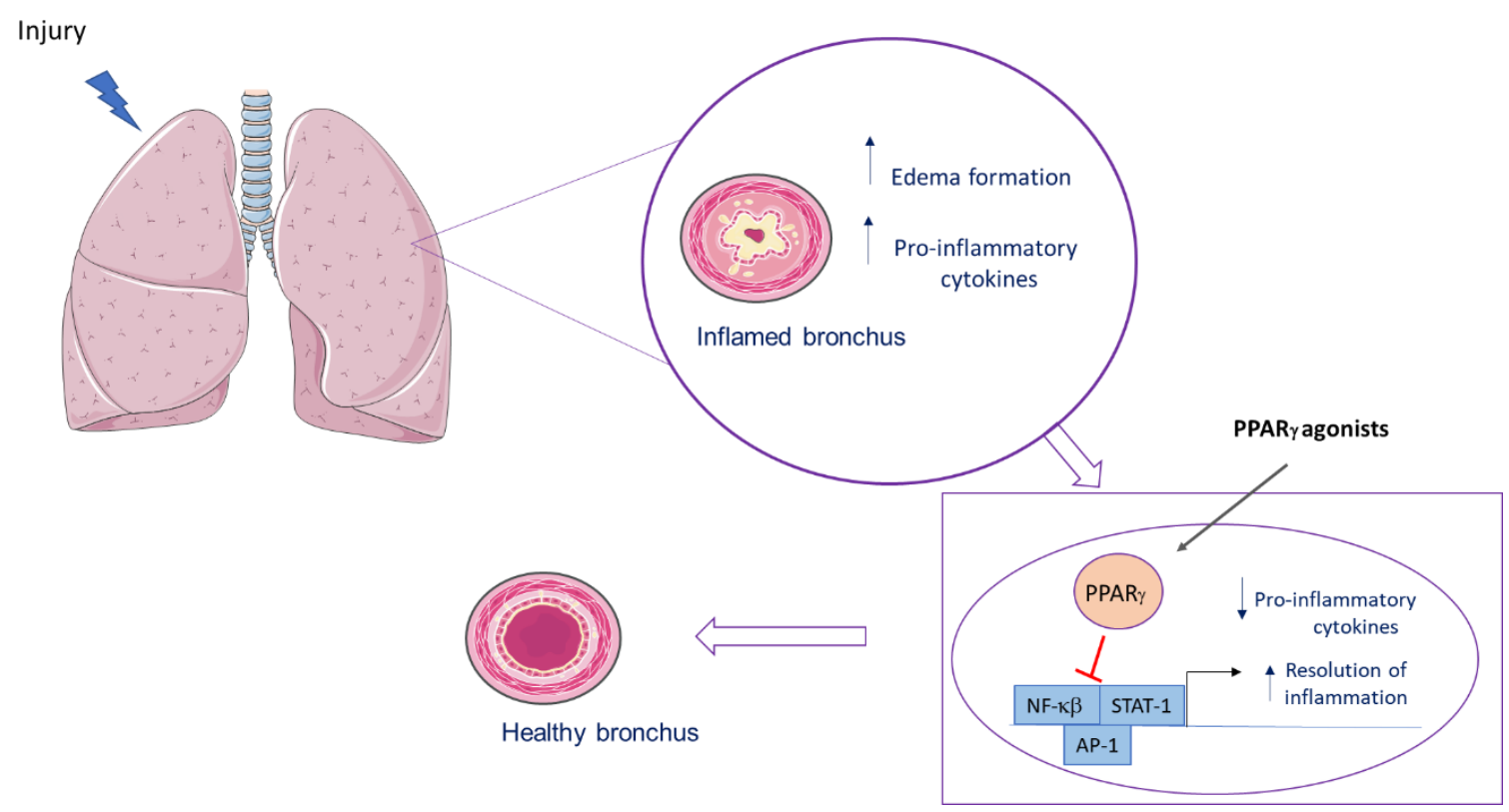

Figure 2. PPAR $\gamma$ role in pulmonary inflammation.

\section{Concluding Remarks Considering Experimental Findings and Clinical Trials}

Most of the reports discuss the anti-inflammatory role of PPAR $\gamma$ agonists on cytokine production induced by many agents that cause lung inflammation or infection. Those effects are related to the PPAR $\gamma$-induced transrepression mechanisms by inhibiting transcription factors or by crosstalk with other receptors or adipocytokines with a beneficial effect on different diseases. This evidence highlights PPAR $\gamma$ as a potential target for adjunct therapy in lung diseases.

Clinical studies with PPAR $\gamma$ agonists based on experimental findings show their effects on disease outcome. Experimental evidence looks promising because of the broad effects of PPAR $\gamma$ ligands controlling the function of many cell types, regulating metabolism and immune response. PPAR $\gamma$ induces and represses transcription, interacts with coactivators and co-receptors and has non-genomic effects. The broad gamma of mechanisms and multiple targets reinforces PPAR $\gamma$ 's role in controlling many biological effects. PPAR $\gamma$ binds to structurally different ligands at different sites of its binding pocket, a phenomenon that may explain various effects, and is also used as a target for new drug design studies.

The role of pioglitazone in metabolic syndrome is well established, because it reduced the risk of cardiovascular events in diabetic insulin-resistant patients, and decreased the progression of atheroma and even diabetes incidence [187].

PPAR $\gamma$ agonists induce differentiation and apoptosis, and prevent proliferation, effects that may help to decrease cancer incidence and progression [87,91]. Pioglitazone associated with imatinibe diminished cancer development [188]. Clinical evidence shows synergism between PPAR $\gamma$ agonist with a chemotherapeutic agent in lung cancer [91].

Some clinical trials show that the use of PPAR $\gamma$ agonists should be analyzed with caution. In a randomized, placebo-controlled, double-blinded, crossover clinical trial, pioglitazone did not improve the primary outcome score in severe asthmatics [189]. There was no efficacy of pioglitazone treatment for 12 weeks in mild asthma management [190].

At the site of the binding pocket, the PPAR $\gamma$ ligand binding affects the PPAR $\gamma$ effect, and we may also consider the dose and the duration of the treatment. Studies with longduration treatment were not conclusive and showed no benefits, but acute administration of PPAR $\gamma$ agonists was associated with a reduction in the risk of pneumonia, suggesting a beneficial effect of acute treatment with PPAR $\gamma$ agonists [11]. Concerning bacterial infections, as in cancer, the best result is obtained with the use of the PPAR $\gamma$ agonist as 
an adjuvant treatment, associated with the current treatment, as antibiotics in the former case [11,191]. By blocking immune response, PPAR $\gamma$ agonists' chronic prescription must be used with caution to prevent bacterial and viral infections.

More than 500 trials with pioglitazone, considered the safest PPAR $\gamma$ agonist in terms of side effects, have been performed worldwide and are still under development [192]. More studies and clinical trials are needed in the field.

Author Contributions: Conceptualization, writing-original draft preparation and editing, funding acquisition-M.V.d.C., C.F.G.-d.-A. and A.R.S.; review-A.R.S. and C.F.G.-d.-A. All authors have read and agreed to the published version of the manuscript.

Funding: This research was funded by Instituto Oswaldo Cruz, Fundação Oswaldo Cruz (FIOCRUZ), Coordenação de Aperfeiçoamento de Pessoal de Nível Superior (CAPES) Grant 001, Programa de Neurociências da Universidade Federal Fluminense (UFF), Universidade Federal do Estado do Rio de Janeiro (Unirio), Fundação Carlos Chagas Filho de Amparo à Pesquisa do Estado do Rio de Janeiro (FAPERJ), Conselho Nacional de Desenvolvimento Científico e Tecnológico (CNPq).

Conflicts of Interest: The authors declare no conflict of interest. The funders had no role in the design of the study; in the collection, analyses, or interpretation of data; in the writing of the manuscript, or in the decision to publish the results.

$\begin{array}{ll}\text { Abbreviations } & \\ \text { ACE2 } & \text { Angiotensin-converting enzyme 2 } \\ \text { AMPK } & \text { Cyclic adenosine monophosphate kinase } \\ \text { AKT } & \text { Protein kinase B } \\ \text { AP-1 } & \text { Activator Protein 1 } \\ \text { ARDS } & \text { Acute respiratory distress syndrome } \\ \text { BALF } & \text { Bronchoalveolar lavage flui } \\ \text { CFTR } & \\ \text { COPD } & \text { Chronic obstructive pulmonary disease } \\ \text { COVID-19 } & \text { Coronavirus disease 19 } \\ \text { COX } & \text { Cycloxygenase } \\ \text { Cq1 } & \text { Complement component 1q } \\ \text { cAMP } & \text { Cyclic adenosine monophosphate } \\ \text { CFTR } & \text { Cystic fibrosis transmembrane conductance regulator } \\ \text { CREB } & \text { cAMP-response element binding protein } \\ \text { CX3CR1 } & \text { CX3C chemokine receptor 1 } \\ \text { DHA } & \text { Docosahexaenoic acid } \\ \text { EPA } & \text { Eicosapentaenoic acid } \\ \text { ERK } & \text { Extracellular signal-regulated kinase } \\ \text { FAM3A } & \text { Family with sequence similarity 3 A } \\ \text { HDAC } & \text { Histone deacethylase } \\ \text { HO-1 } & \text { Hemoxygenase-1 } \\ \text { ICAM-1 } & \text { Intercellular adhesion molecule 1 } \\ \text { JAK } & \text { Janus kinase } \\ \text { LPS } & \text { Lipopolysaccharide } \\ \text { MAP } & \text { Mitogen-activated kinase } \\ \text { MRSA } & \text { Methicillin-resistant Staphylococcus aureus } \\ \text { NAD } & \text { Nicotinamide adenine dinucleotide } \\ \text { NHANES } & \text { National Health and Nutrition Examination Survey } \\ \text { NEDD4 } & \text { Neural precursor cell expressed developmentally } \\ \text { NCOR } & \text { downregulated protein 4 } \\ \text { NFKB } & \text { Nuclear receptor co-repressor } \\ \text { NK } & \text { Nuclear factor kappa B } \\ \text { PG } & \text { Natural Killer } \\ \text { PKA } & \text { Prostaglandin } \\ \text { PKB } & \text { Protein kinase A } \\ & \end{array}$




$\begin{array}{ll}\text { PKC } & \text { Protein kinase C } \\ \text { PPAR } \gamma & \text { Peroxisome proliferator-activated receptor } \gamma \\ \text { PTEN } & \text { Phosphatase and tensin homolog } \\ \text { PTM } & \text { Post-translational mechanisms } \\ \text { SARS-CoV-2 } & \text { Severe acute respiratory syndrome coronavirus } 2 \\ \text { SOCS } & \text { Suppressor of cytokine signaling protein } \\ \text { STAT } & \text { Signal transducers and activators of transcription } \\ \text { SUMO } & \text { Small ubiquitin-like modifier } \\ \text { TFEB } & \text { Transcription factor EB } \\ \text { TLR } & \text { Toll-like receptor } \\ \text { TREM-2 } & \text { Triggering receptor expressed on myeloid cells } \\ \text { TRIM23 } & \text { Tripartite motif containing 23 } \\ \text { TZD } & \text { Thiazolidinedione } \\ \text { VCAM-1 } & \text { Vascular cell adhesion molecule 1 } \\ \text { wnt } & \text { Homologous wingless and Int-1 }\end{array}$

\section{References}

1. Han, L.; Shen, W.-J.; Bittner, S.; Kraemer, F.B.; Azhar, S. PPARs: Regulators of metabolism and as therapeutic targets in cardiovascular disease. Part II: PPAR- $\beta / \delta$ and PPAR- $\gamma$. Future Cardiol. 2017, 13, 279-296. [CrossRef] [PubMed]

2. Dreyer, C.; Krey, G.; Keller, H.; Givel, F.; Helftenbein, G.; Wahli, W. Control of the peroxisomal $\beta$-oxidation pathway by a novel family of nuclear hormone receptors. Cell 1992, 68, 879-887. [CrossRef]

3. Issemann, I.; Green, S. Activation of a member of the steroid hormone receptor superfamily by peroxisome proliferators. Nature 1990, 347, 645-650. [CrossRef] [PubMed]

4. Kliewer, S.A.; Forman, B.M.; Blumberg, B.; Ong, E.S.; Borgmeyer, U.; Mangelsdorf, D.J.; Umesono, K.; Evans, R.M. Differential expression and activation of a family of murine peroxisome proliferator-activated receptors. Proc. Natl. Acad. Sci. USA 1994, 91, 7355-7359. [CrossRef]

5. Strand, D.W.; Jiang, M.; Murphy, T.A.; Yi, Y.; Konvinse, K.C.; Franco, O.E.; Wang, Y.; Young, J.D.; Hayward, S.W. PPAR $\gamma$ isoforms differentially regulate metabolic networks to mediate mouse prostatic epithelial differentiation. Cell Death Dis. 2012,3 , e361. [CrossRef]

6. Shao, X.; Wang, M.; Wei, X.; Deng, S.; Fu, N.; Peng, Q.; Jiang, Y.; Ye, L.; Xie, J.; Lin, Y. Peroxisome Proliferator-Activated Receptor- $\gamma$ : Master Regulator of Adipogenesis and Obesity. Curr. Stem Cell Res. Ther. 2016, 11, 282-289. [CrossRef]

7. Mirza, R.E.; Fang, M.M.; Novak, M.L.; Urao, N.; Sui, A.; Ennis, W.J.; Koh, T.J. Macrophage PPAR $\gamma$ and impaired wound healing in type 2 diabetes. J. Pathol. 2015, 236, 433-444. [CrossRef]

8. Byndloss, M.X.; Olsan, E.E.; Rivera-Chávez, F.; Tiffany, C.R.; Cevallos, S.A.; Lokken, K.L.; Torres, T.P.; Byndloss, A.J.; Faber, F.; Gao, Y.; et al. Microbiota-activated PPAR- $\gamma$ signaling inhibits dysbiotic Enterobacteriaceae expansion. Science 2017, 357, 570-575. [CrossRef]

9. Araújo, C.V.; Campbell, C.; Gonçalves-De-Albuquerque, C.F.; Molinaro, R.; Cody, M.J.; Yost, C.C.; Bozza, P.T.; Zimmerman, G.A.; Weyrich, A.S.; Castro-Faria-Neto, H.C.; et al. A Ppar $\gamma$ Agonist Enhances Bacterial Clearance Through Neutrophil Extracellular TRAP formation and Improves Survival in Sepsis. Shock 2016, 45, 393-403. [CrossRef]

10. Araújo, C.; Estato, V.; Tibiriça, E.; Bozza, P.T.; Castro-Faria-Neto, H.; Silva, A.R. PPAR gamma activation protects the brain against microvascular dysfunction in sepsis. Microvasc. Res. 2012, 84, 218-221. [CrossRef]

11. Silva, A.R.; Gonçalves-De-Albuquerque, C.F.; Pérez, A.R.; Carvalho, V.F. Immune-endocrine interactions related to a high risk of infections in chronic metabolic diseases: The role of PPAR gamma. Eur. J. Pharmacol. 2019, 854, 272-281. [CrossRef] [PubMed]

12. Villapol, S. Roles of Peroxisome Proliferator-Activated Receptor Gamma on Brain and Peripheral Inflammation. Cell. Mol. Neurobiol. 2017, 38, 121-132. [CrossRef] [PubMed]

13. Janani, C.; Kumari, B.R. PPAR gamma gene-A review. Diabetes Metab. Syndr. Clin. Res. Rev. 2015, 9, 46-50. [CrossRef]

14. Moseti, D.; Regassa, A.; Kim, W.K. Molecular Regulation of Adipogenesis and Potential Anti-Adipogenic Bioactive Molecules. Int. J. Mol. Sci. 2016, 17, 124. [CrossRef] [PubMed]

15. Salgia, M.M.; Elix, C.C.; Pal, S.K.; Jones, J.O. Different roles of peroxisome proliferator-activated receptor gamma isoforms in prostate cancer. Am. J. Clin. Exp. Urol. 2019, 7, 98-109.

16. Chen, K.; Li, J.; Wang, J.; Xia, Y.; Dai, W.; Wang, F.; Shen, M.; Cheng, P.; Zhang, Y.; Wang, C.; et al. 15-Deoxy- $\gamma 12,14-$ prostaglandin J2 Reduces Liver Impairment in a Model of ConA-Induced Acute Hepatic Inflammation by Activation of PPAR $\gamma$ and Reduction in NF-кB Activity. PPAR Res. 2014, 2014, 1-10. [CrossRef]

17. Rolland, M.; Li, X.; Sellier, Y.; Martin, H.; Pérez-Berezo, T.; Rauwel, B.; Benchoua, A.; Bessières, B.; Aziza, J.; Cenac, N.; et al. PPAR $\gamma$ Is Activated during Congenital Cytomegalovirus Infection and Inhibits Neuronogenesis from Human Neural Stem Cells. PLoS Pathog. 2016, 12, e1005547. [CrossRef]

18. Narala, V.R.; Subramani, P.A.; Narasimha, V.R.; Shaik, F.B.; Panati, K. The role of nitrated fatty acids and peroxisome proliferatoractivated receptor gamma in modulating inflammation. Int. Immunopharmacol. 2014, 23, 283-287. [CrossRef] 
19. Elferink, R.P.O.; Bolier, R.; Beuers, U. Lysophosphatidic acid and signaling in sensory neurons. Biochim. et Biophys. Acta (BBA) Mol. Cell Biol. Lipids 2015, 1851, 61-65. [CrossRef]

20. Han, W.; Zhao, H.; Jiao, B.; Liu, F. EPA and DHA increased PPAR $\gamma$ expression and deceased integrin-linked kinase and integrin $\beta 1$ expression in rat glomerular mesangial cells treated with lipopolysaccharide. Biosci. Trends 2014, 8, 120-125. [CrossRef]

21. Takada, I.; Makishima, M. Peroxisome proliferator-activated receptor agonists and antagonists: A patent review (2014-present). Expert Opin. Ther. Patents 2019, 30,1-13. [CrossRef] [PubMed]

22. Wang, X.; Wang, Y.; Hu, J.-P.; Yu, S.; Li, B.-K.; Cui, Y.; Ren, L.; Zhang, L.-D. Astragaloside IV, a Natural PPAR $\gamma$ Agonist, Reduces A $\beta$ Production in Alzheimer's Disease Through Inhibition of BACE 1. Mol. Neurobiol. 2016, 54, 2939-2949. [CrossRef] [PubMed]

23. Han, Q.; Yuan, Q.; Meng, X.; Huo, J.; Bao, Y.; Xie, G. 6-Shogaol attenuates LPS-induced inflammation in BV2 microglia cells by activating PPAR- $\gamma$. Oncotarget 2017, 8, 42001-42006. [CrossRef] [PubMed]

24. Shi, L.; Lin, Q.; Li, X.; Nie, Y.; Sun, S.; Deng, X.; Wang, L.; Lu, J.; Tang, Y.; Luo, F. Alliin, a garlic organosulfur compound, ameliorates gut inflammation through MAPK-NF-кB/AP-1/STAT-1 inactivation and PPAR- $\gamma$ activation. Mol. Nutr. Food Res. 2017, 61, 1601013. [CrossRef] [PubMed]

25. Vallée, J.-N.; LeCarpentier, Y.; Guillevin, R.; Vallée, J.-N. Effects of cannabidiol interactions with Wnt/ $\beta$-catenin pathway and PPAR $\gamma$ on oxidative stress and neuroinflammation in Alzheimer's disease. Acta Biochim. Biophys. Sin. 2017, 49, 853-866. [CrossRef]

26. Zhang, Y.; Fu, L.; Tang, F. The protective effects of magnolol on acute trinitrobenzene sulfonic acid-induced colitis in rats. Mol. Med. Rep. 2017, 17, 3455-3464. [CrossRef]

27. Serra, D.; Almeida, L.M.; Dinis, T.C.P. Anti-inflammatory protection afforded by cyanidin-3-glucoside and resveratrol in human intestinal cells via Nrf2 and PPAR- $\gamma$ : Comparison with 5-aminosalicylic acid. Chem. Interact. 2016, 260, 102-109. [CrossRef]

28. Zhu, T.; Chen, Z.; Chen, G.; Wang, D.; Tang, S.; Deng, H.; Wang, J.; Li, S.; Lan, J.; Tong, J.; et al. Curcumin Attenuates Asthmatic Airway Inflammation and Mucus Hypersecretion Involving a PPAR $\gamma$-Dependent NF-kB Signaling Pathway In Vivo and In Vitro. Mediat. Inflamm. 2019, 2019, 4927430-15. [CrossRef]

29. Medeiros-De-Moraes, I.M.; Gonçalves-De-Albuquerque, C.F.; Kurz, A.R.M.; Oliveira, F.M.D.J.; De Abreu, V.H.P.; Torres, R.; Carvalho, V.F.; Estato, V.; Bozza, P.T.; Sperandio, M.; et al. Omega-9 Oleic Acid, the Main Compound of Olive Oil, Mitigates Inflammation during Experimental Sepsis. Oxidative Med. Cell. Longev. 2018, 2018, 1-13. [CrossRef]

30. Silva, A.R.; Moraes, B.P.T.; Gonçalves-De-Albuquerque, C.F. Mediterranean Diet: Lipids, Inflammation, and Malaria Infection. Int. J. Mol. Sci. 2020, 21, 4489. [CrossRef]

31. Jia, Y.; Kim, J.-Y.; Jun, H.-J.; Kim, S.-J.; Lee, J.-H.; Hoang, M.H.; Hwang, K.-Y.; Um, S.-J.; Chang, H.-I.; Lee, S.-J. The natural carotenoid astaxanthin, a PPAR- $\alpha$ agonist and PPAR $-\gamma$ antagonist, reduces hepatic lipid accumulation by rewiring the transcriptome in lipid-loaded hepatocytes. Mol. Nutr. Food Res. 2012, 56, 878-888. [CrossRef] [PubMed]

32. Lehmann, J.M.; Moore, L.B.; Smith-Oliver, T.A.; Wilkison, W.O.; Willson, T.M.; Kliewer, S.A. An Antidiabetic Thiazolidinedione Is a High Affinity Ligand for Peroxisome Proliferator-activated Receptor $\gamma$ (PPAR $\gamma$ ). J. Biol. Chem. 1995, 270, 12953-12956. [CrossRef] [PubMed]

33. Miller, J.L. Rosiglitazone approved for treatment of type 2 diabetes. Am. J. Heal. Pharm. 1999, 56, 1292. [CrossRef] [PubMed]

34. Cariou, B.; Charbonnel, B.; Staels, B. Thiazolidinediones and PPAR $\gamma$ agonists: Time for a reassessment. Trends Endocrinol. Metab. 2012, 23, 205-215. [CrossRef] [PubMed]

35. Takada, I.; Makishima, M. PPAR $\gamma$ ligands and their therapeutic applications: A patent review (2008-2014). Expert Opin. Ther. Patents 2014, 25, 175-191. [CrossRef] [PubMed]

36. Liu, C.; Liu, R.; Fu, H.; Li, J.; Wang, X.; Cheng, L.; Korantzopoulos, P.; Tse, G.; Li, G.; Liu, T. Pioglitazone attenuates atrial remodeling and vulnerability to atrial fibrillation in alloxan-induced diabetic rabbits. Cardiovasc. Ther. 2017, 35, e12284. [CrossRef]

37. Legchenko, E.; Chouvarine, P.; Borchert, P.; Fernandez-Gonzalez, A.; Snay, E.; Meier, M.; Maegel, L.; Mitsialis, S.A.; Rog-Zielinska, E.A.; Kourembanas, S.; et al. PPAR $\gamma$ agonist pioglitazone reverses pulmonary hypertension and prevents right heart failure via fatty acid oxidation. Sci. Transl. Med. 2018, 10, eaao0303. [CrossRef]

38. Brunmeir, R.; Xu, F. Functional Regulation of PPARs through Post-Translational Modifications. Int. J. Mol. Sci. 2018, 19, 1738. [CrossRef]

39. Fang, T.; Di, Y.; Li, G.; Cui, X.; Shen, N.; Li, Y.; Xi, P.; Xie, Y.; Tian, F.; Li, G. Effects of telmisartan on TNF $\alpha$ induced PPAR $\gamma$ phosphorylation and insulin resistance in adipocytes. Biochem. Biophys. Res. Commun. 2018, 503, 3044-3049. [CrossRef]

40. Bhatt, K.H.; Sodhi, A.; Chakraborty, R. Peptidoglycan induced expression of peroxisome proliferator-activated receptor $\gamma$ in mouse peritoneal macrophages: Role of ERK and JNK MAP kinases. Cytokine 2012, 60, 778-786. [CrossRef]

41. Choi, M.-J.; Lee, E.-J.; Park, J.-S.; Kim, S.-N.; Park, E.-M.; Kim, H.-S. Anti-inflammatory mechanism of galangin in lipopolysaccharide-stimulated microglia: Critical role of PPAR- $\gamma$ signaling pathway. Biochem. Pharmacol. 2017, 144, 120-131. [CrossRef]

42. Hu, T.; Lin, Q.; Guo, T.; Yang, T.; Zhou, W.; Deng, X.; Yan, J.-K.; Luo, Y.; Ju, M.; Luo, F. Polysaccharide isolated from Phellinus linteus mycelia exerts anti-inflammatory effects via MAPK and PPAR signaling pathways. Carbohydr. Polym. 2018, $200,487-497$. [CrossRef] [PubMed]

43. Huang, C.; Yang, Y.; Li, W.-X.; Wu, X.-Q.; Li, X.-F.; Ma, T.-T.; Zhang, L.; Meng, X.-M.; Li, J. Hyperin attenuates inflammation by activating PPAR- $\gamma$ in mice with acute liver injury (ALI) and LPS-induced RAW264.7 cells. Int. Immunopharmacol. 2015, 29, 440-447. [CrossRef] [PubMed] 
44. Lu, Y.; Zhou, Q.; Shi, Y.; Liu, J.; Zhong, F.; Hao, X.; Li, C.; Chen, N.; Wang, W. SUMOylation of PPAR $\gamma$ by Rosiglitazone Prevents LPS-Induced NCoR Degradation Mediating Down Regulation of Chemokines Expression in Renal Proximal Tubular Cells. PLoS ONE 2013, 8, e79815. [CrossRef] [PubMed]

45. Eifler, K.; Vertegaal, A.C. SUMOylation-Mediated Regulation of Cell Cycle Progression and Cancer. Trends Biochem. Sci. 2015, 40, 779-793. [CrossRef]

46. Zelcer, N.; Tontonoz, P. SUMOylation and PPAR $\gamma$ : Wrestling with inflammatory signaling. Cell Metab. 2005, 2, 273-275. [CrossRef]

47. Pascual, G.; Fong, A.L.; Ogawa, S.; Gamliel, A.; Li, A.C.; Perissi, V.; Rose, D.W.; Willson, T.M.; Rosenfeld, M.G.; Glass, C.K. A SUMOylation-dependent pathway mediates transrepression of inflammatory response genes by PPAR- $\gamma$. Nature 2005, 437, 759-763. [CrossRef] [PubMed]

48. Bailey, S.T.; Ghosh, S. 'PPAR'ting ways with inflammation. Nat. Immunol. 2005, 6, 966-967. [CrossRef]

49. Jennewein, C.; Kuhn, A.-M.; Schmidt, M.V.; Meilladec-Jullig, V.; Von Knethen, A.; Gonzalez, FJ.; Brüne, B. Sumoylation of PPAR $\gamma$ by apoptotic cells prevents LPS-induced NCoR removal from $\mathrm{\kappa B}$ binding sites mediating transrepression of pro-inflammatory cytokines. J. Immunol. 2008, 181, 5646-5652. [CrossRef]

50. Li, J.-J.; Wang, R.; Lama, R.; Wang, X.; Floyd, Z.E.; Park, E.A.; Liao, F.-F. Ubiquitin Ligase NEDD4 Regulates PPAR $\gamma$ Stability and Adipocyte Differentiation in 3T3-L1 Cells. Sci. Rep. 2016, 6, 38550. [CrossRef]

51. Watanabe, M.; Takahashi, H.; Saeki, Y.; Ozaki, T.; Itoh, S.; Suzuki, M.; Mizushima, W.; Tanaka, K.; Hatakeyama, S. The E3 ubiquitin ligase TRIM23 regulates adipocyte differentiation via stabilization of the adipogenic activator PPAR $\gamma$. eLife 2015, 4, e05615. [CrossRef] [PubMed]

52. Qiang, L.; Wang, L.; Kon, N.; Zhao, W.; Lee, S.; Zhang, Y.; Rosenbaum, M.; Zhao, Y.; Gu, W.; Farmer, S.R.; et al. Brown remodeling of white adipose tissue by SirT1-dependent deacetylation of Ppar $\gamma$. Cell 2012, 150, 620-632. [CrossRef]

53. Ji, S.; Park, S.Y.; Roth, J.; Kim, H.S.; Cho, J.W. O-GlcNAc modification of PPAR $\gamma$ reduces its transcriptional activity. Biochem. Biophys. Res. Commun. 2012, 417, 1158-1163. [CrossRef] [PubMed]

54. Netea, M.G.; Balkwill, F.; Chonchol, M.; Cominelli, F.; Donath, M.Y.; Giamarellos-Bourboulis, E.J.; Golenbock, U.; Gresnigt, M.S.; Heneka, M.T.; Hoffman, H.M.; et al. A guiding map for inflammation. Nat. Immunol. 2017, 18, 826-831. [CrossRef] [PubMed]

55. Al-Soudi, A.; Kaaij, M.; Tas, S.W. Endothelial cells: From innocent bystanders to active participants in immune responses. Autoimmun. Rev. 2017, 16, 951-962. [CrossRef] [PubMed]

56. Rescigno, M. Dendritic cell-epithelial cell crosstalk in the gut. Immunol. Rev. 2014, 260, 118-128. [CrossRef] [PubMed]

57. Medzhitov, R. Origin and physiological roles of inflammation. Nature 2008, 454, 428-435. [CrossRef]

58. Ushiki, T.; Huntington, N.D.; Glaser, S.P.; Kiu, H.; Georgiou, A.; Zhang, J.-G.; Metcalf, D.; Nicola, N.A.; Roberts, A.W.; Alexander, W.S. Rapid Inflammation in Mice Lacking Both SOCS1 and SOCS3 in Hematopoietic Cells. PLoS ONE 2016, 11, e0162111. [CrossRef]

59. O'Connor, P.W. Natalizumab and the role of $\alpha 4$-integrin antagonism in the treatment of multiple sclerosis. Expert Opin. Biol. Ther. 2006, 7, 123-136. [CrossRef]

60. Hajishengallis, G.; Reis, E.S.; Mastellos, D.C.; Ricklin, D.; Lambris, J.D. Novel mechanisms and functions of complement. Nat. Immunol. 2017, 18, 1288-1298. [CrossRef]

61. Croasdell, A.; Duffney, P.F.; Kim, N.; Lacy, S.H.; Sime, P.J.; Phipps, R.P. PPAR $\gamma$ and the Innate Immune System Mediate the Resolution of Inflammation. PPAR Res. 2015, 2015, 1-20. [CrossRef] [PubMed]

62. Smale, S.T. Selective Transcription in Response to an Inflammatory Stimulus. Cell 2010, 140, 833-844. [CrossRef] [PubMed]

63. Koues, O.I.; Collins, P.L.; Cella, M.; Robinette, M.L.; Porter, S.I.; Pyfrom, S.C.; Payton, J.E.; Colonna, M.; Oltz, E.M. Distinct Gene Regulatory Pathways for Human Innate versus Adaptive Lymphoid Cells. Cell 2016, 165, 1134-1146. [CrossRef] [PubMed]

64. Hawiger, J.; Zienkiewicz, J. Decoding inflammation, its causes, genomic responses, and emerging countermeasures. Scand. J. Immunol. 2019, 90, e12812. [CrossRef]

65. Ran, L.; Yu, Q.; Zhang, S.; Xiong, F.; Cheng, J.; Yang, P.; Xu, J.-F.; Nie, H.; Zhong, Q.; Yang, X.; et al. Cx3cr1 deficiency in mice attenuates hepatic granuloma formation during acute schistosomiasis by enhancing the M2-type polarization of macrophages. Dis. Model. Mech. 2015, 8, 691-700. [CrossRef] [PubMed]

66. Ho, M.-M.; Manughian-Peter, A.O.; Spivia, W.R.; Taylor, A.; Fraser, D.A. Macrophage molecular signaling and inflammatory responses during ingestion of atherogenic lipoproteins are modulated by complement protein C1q. Atherosclerosis 2016, 253, 38-46. [CrossRef]

67. Geng, L.; Zhang, T.; Liu, W.; Chen, Y. Inhibition of miR-128 Abates A $\beta$-Mediated Cytotoxicity by Targeting PPAR- $\gamma$ via NF- $к B$ Inactivation in Primary Mouse Cortical Neurons and Neuro2a Cells. Yonsei Med. J. 2018, 59, 1096-1106. [CrossRef]

68. Khosravi, F.; Kharazmi, F.; Kamran, M.; Malekzadeh, K.; Talebi, A.; Soltani, N. The role of PPAR- $\gamma$ and NFKB genes expression in muscle to improve hyperglycemia in STZ-induced diabetic rat following magnesium sulfate administration. Int. J. Physiol. Pathophysiol. Pharmacol. 2018, 10, 124-131.

69. Liu, Y.; Chen, S.; Liu, J.; Jin, Y.; Yu, S.; An, R. Telmisartan inhibits oxalate and calcium oxalate crystal-induced epithelialmesenchymal transformation via PPAR- $\gamma$-AKT/STAT3/p38 MAPK-Snail pathway. Life Sci. 2020, 241, 117108. [CrossRef]

70. Zhao, M.; Bian, Y.; Yang, L.-L.; Chen, Y.-Q.; Wang, Y.-J.; Ma, Y.-T.; Pei, Y.-Q.; Li, W.-L.; Zeng, L. HuoXueTongFu Formula Alleviates Intraperitoneal Adhesion by Regulating Macrophage Polarization and the SOCS/JAK2/STAT/PPAR- $\gamma$ Signalling Pathway. Mediat. Inflamm. 2019, 2019, 1769374-17. [CrossRef] 
71. De Jong, E.; Winkel, P.; Poelstra, K.; Prakash, J. Anticancer Effects of 15d-Prostaglandin-J2 in Wild-Type and Doxorubicin-Resistant Ovarian Cancer Cells: Novel Actions on SIRT1 and HDAC. PLoS ONE 2011, 6, e25192. [CrossRef] [PubMed]

72. Xiong, Z.; Luo, P.; Zhou, J.; Tan, M. 15-Deoxy- $\Delta 12,14$-prostaglandin J2 as a potential regulator of bone metabolism via PPAR $\gamma$ dependent and independent pathways: A review. Drug Des. Dev. Ther. 2019, 13, 1879-1888. [CrossRef] [PubMed]

73. Jiang, H.; Zhou, X.E.; Shi, J.; Zhou, Z.; Zhao, G.; Zhang, X.; Sun, Y.; Suino-Powell, K.; Ma, L.; Gao, H.; et al. Identification and structural insight of an effective PPAR $\gamma$ modulator with improved therapeutic index for anti-diabetic drug discovery. Chem. Sci. 2020, 11, 2260-2268. [CrossRef] [PubMed]

74. Lakshmi, S.P.; Reddy, A.T.; Reddy, R.C. Emerging pharmaceutical therapies for COPD. Int. J. Chronic Obstr. Pulm. Dis. 2017, 12, 2141-2156. [CrossRef]

75. Mazidi, M.; Karimi, E.; Meydani, M.; Avan, A.; Ferns, G.A. Potential effects of curcumin on peroxisome proliferator-activated receptor- $\gamma$ in vitroandin vivo. World J. Methodol. 2016, 6, 112-117. [CrossRef]

76. Jacob, A.; Wu, R.; Zhou, M.; Wang, P. Mechanism of the Anti-inflammatory Effect of Curcumin: PPAR- $\gamma$ Activation. PPAR Res. 2008, 2007, 1-5. [CrossRef]

77. Dreier, D.; Latkolik, S.; Rycek, L.; Schnürch, M.; Dymáková, A.; Atanasov, A.G.; Ladurner, A.; Heiss, E.H.; Stuppner, H.; Schuster, D.; et al. Linked magnolol dimer as a selective PPAR $\gamma$ agonist - Structure-based rational design, synthesis, and bioactivity evaluation. Sci. Rep. 2017, 7, 13002. [CrossRef]

78. Aldridge, J.R.; Moseley, C.E.; Boltz, D.A.; Negovetich, N.J.; Reynolds, C.; Franks, J.; Brown, S.A.; Doherty, P.C.; Webster, R.G.; Thomas, P.G. TNF/iNOS-producing dendritic cells are the necessary evil of lethal influenza virus infection. Proc. Natl. Acad. Sci. USA 2009, 106, 5306-5311. [CrossRef]

79. Venkataraman, B.; Ojha, S.; Belur, P.D.; Bhongade, B.; Raj, V.; Collin, P.D.; Adrian, T.E.; Subramanya, S.B. Phytochemical drug candidates for the modulation of peroxisome proliferator-activated receptor $\gamma$ in inflammatory bowel diseases. Phytotherapy Res. 2020, 34, 1530-1549. [CrossRef]

80. Linares-Cervantes, I.; Farrokhi, K.; Echeverri, J.; Kaths, J.M.; Kollmann, D.; Hamar, M.; Urbanellis, P.; Ganesh, S.; Adeyi, O.; Yip, P.; et al. PPAR-gamma activation is associated with reduced liver ischemia-reperfusion injury and altered tissue-resident macrophages polarization in a mouse model. PLOS ONE 2018, 13, e0195212. [CrossRef]

81. Yang, W.; Chen, J.; Meng, Y.; Chen, Z.; Yang, J. Novel Targets for Treating Ischemia-Reperfusion Injury in the Liver. Int. J. Mol. Sci. 2018, 19, 1302. [CrossRef] [PubMed]

82. Chen, Y.; Liu, S.; Chen, G. Aggravation of Cerebral Ischemia/Reperfusion Injury by Peroxisome Proliferator-Activated ReceptorGamma Deficiency via Endoplasmic Reticulum Stress. Med. Sci. Monit. 2019, 25, 7518-7526. [CrossRef] [PubMed]

83. Elshazly, S.; Soliman, E. PPAR gamma agonist, pioglitazone, rescues liver damage induced by renal ischemia/reperfusion injury. Toxicol. Appl. Pharmacol. 2019, 362, 86-94. [CrossRef] [PubMed]

84. Ciavarella, C.; Motta, I.; Valente, S.; Pasquinelli, G. Pharmacological (or Synthetic) and Nutritional Agonists of PPAR- $\gamma$ as Candidates for Cytokine Storm Modulation in COVID-19 Disease. Molecules 2020, 25, 2076. [CrossRef] [PubMed]

85. Chichger, H.; Rounds, S.; Harrington, E.O. Endosomes and Autophagy: Regulators of Pulmonary Endothelial Cell Homeostasis in Health and Disease. Antioxidants Redox Signal. 2019, 31, 994-1008. [CrossRef] [PubMed]

86. Giaginis, C.; Tsourouflis, G.; Theocharis, S. Peroxisome Proliferator-Activated Receptor- $\gamma$ (PPAR- $\gamma$ ) Ligands: Novel Pharmacological Agents in the Treatment of Ischemia Reperfusion Injury. Curr. Mol. Med. 2008, 8, 562-579. [CrossRef] [PubMed]

87. Lakshmi, S.P.; Reddy, A.T.; Banno, A.; Reddy, R.C. PPAR Agonists for the Prevention and Treatment of Lung Cancer. PPAR Res. 2017, 2017, 1-8. [CrossRef]

88. Huang, G.; Yin, L.-M.; Lan, J.; Tong, R.; Li, M.; Na, F.; Mo, X.; Chen, C.; Xue, J.-X.; Lu, Y. Synergy between peroxisome proliferator-activated receptor $\gamma$ agonist and radiotherapy in cancer. Cancer Sci. 2018, 109, 2243-2255. [CrossRef]

89. New, M.; White, C.M.; Mcgonigle, P.; McArthur, D.G.; Dwyer-Nield, L.D.; Merrick, D.T.; Keith, R.L.; Tennis, M.A. Prostacyclin and EMT Pathway Markers for Monitoring Response to Lung Cancer Chemoprevention. Cancer Prev. Res. 2018, 11, 643-654. [CrossRef]

90. Ammu, V.R.K.; Garikapati, K.K.; Krishnamurthy, P.T.; Chintamaneni, P.K.; Pindiprolu, S.K.S. Possible role of PPAR- $\gamma$ and COX-2 receptor modulators in the treatment of Non-Small Cell lung carcinoma. Med. Hypotheses 2019, 124, 98-100. [CrossRef]

91. Reddy, A.T.; Lakshmi, S.P.; Reddy, R.C. PPAR $\gamma$ as a Novel Therapeutic Target in Lung Cancer. PPAR Res. 2016, 2016, 1-7. [CrossRef]

92. Banno, A.; Reddy, A.T.; Lakshmi, S.P.; Reddy, A.R.C. PPARs: Key Regulators of Airway Inflammation and Potential Therapeutic Targets in Asthma. Nucl. Recept. Res. 2018, 5. [CrossRef] [PubMed]

93. Lakshmi, S.P.; Reddy, A.T.; Banno, A.; Reddy, R.C. Airway Epithelial Cell Peroxisome Proliferator-Activated Receptor $\gamma$ Regulates Inflammation and Mucin Expression in Allergic Airway Disease. J. Immunol. 2018, 201, 1775-1783. [CrossRef] [PubMed]

94. Lee, Y.-S.; Yang, W.-K.; Yee, S.-M.; Kim, S.-M.; Park, Y.-C.; Shin, H.J.; Han, C.K.; Kang, H.-S.; Kim, S.-H.; Lee, Y.C. KGC3P attenuates ovalbumin-induced airway inflammation through downregulation of p-PTEN in asthmatic mice. Phytomedicine 2019, 62, 152942. [CrossRef] [PubMed]

95. Rosanna, D.P.; Salvatore, C. Reactive oxygen species, inflammation, and lung diseases. Curr. Pharm. Des. 2012, 18, 3889-3900. [CrossRef]

96. Butt, Y.; Kurdowska, A.; Allen, T.C. Acute Lung Injury: A Clinical and Molecular Review. Arch. Pathol. Lab. Med. 2016, 140, 345-350. [CrossRef] 
97. Meng, F.; Mambetsariev, I.; Tian, Y.; Beckham, Y.; Meliton, A.; Leff, A.; Gardel, M.L.; Allen, M.J.; Birukov, K.G.; Birukova, A.A. Attenuation of Lipopolysaccharide-Induced Lung Vascular Stiffening by Lipoxin Reduces Lung Inflammation. Am. J. Respir. Cell Mol. Biol. 2015, 52, 152-161. [CrossRef]

98. Li, Q.; Sun, J.; Mohammadtursun, N.; Wu, J.; Dong, J.; Li, L. Curcumin inhibits cigarette smoke-induced inflammation via modulating the PPAR $\gamma$-NF-кB signaling pathway. Food Funct. 2019, 10, 7983-7994. [CrossRef]

99. Morissette, M.C.; Shen, P.; Thayaparan, D.; Stampfli, M.R. Impacts of peroxisome proliferator-activated receptor- $\gamma$ activation on cigarette smoke-induced exacerbated response to bacteria. Eur. Respir. J. 2014, 45, 191-200. [CrossRef]

100. Elborn, J. Cystic fibrosis. Lancet 2016, 388, 2519-2531. [CrossRef]

101. Bartoszewski, R.; Rab, A.; Jurkuvenaite, A.; Mazur, M.; Wakefield, J.; Collawn, J.F.; Bebok, Z. Activation of the Unfolded Protein Response by $\triangle$ F508 CFTR. Am. J. Respir. Cell Mol. Biol. 2008, 39, 448-457. [CrossRef]

102. Luciani, A.; Villella, V.R.; Esposito, S.; Brunetti-Pierri, N.; Medina, D.L.; Settembre, C.; Gavina, M.; Pulze, L.; Giardino, I.; Pettoello-Mantovani, M.; et al. Defective CFTR induces aggresome formation and lung inflammation in cystic fibrosis through ROS-mediated autophagy inhibition. Nature 2010, 12, 863-875. [CrossRef] [PubMed]

103. Smerieri, A.; Montanini, L.; Maiuri, L.; Bernasconi, S.; Street, M.E. FOXO1 Content Is Reduced in Cystic Fibrosis and Increases with IGF-I Treatment. Int. J. Mol. Sci. 2014, 15, 18000-18022. [CrossRef] [PubMed]

104. Andersson, C.; Zaman, M.M.; Jones, A.B.; Freedman, S.D. Alterations in immune response and PPAR/LXR regulation in cystic fibrosis macrophages. J. Cyst. Fibros. 2008, 7, 68-78. [CrossRef]

105. Caretti, A.; Vasso, M.; Bonezzi, F.T.; Gallina, A.; Trinchera, M.; Rossi, A.; Adami, R.; Casas, J.; Falleni, M.; Tosi, D.; et al. Myriocin treatment of CF lung infection and inflammation: Complex analyses for enigmatic lipids. Naunyn-Schmiedeberg's Arch. Pharmacol. 2017, 390, 775-790. [CrossRef] [PubMed]

106. Caretti, A.; Torelli, R.; Perdoni, F.; Falleni, M.; Tosi, D.; Zulueta, A.; Casas, J.; Sanguinetti, M.; Ghidoni, R.; Borghi, E.; et al Inhibition of ceramide de novo synthesis by myriocin produces the double effect of reducing pathological inflammation and exerting antifungal activity against A. fumigatus airways infection. Biochim. Biophys. Acta (BBA)-Gen. Subj. 2016, 1860, $1089-1097$. [CrossRef] [PubMed]

107. Kim, Y.S.; Lee, H.-M.; Kim, J.K.; Yang, C.-S.; Kim, T.S.; Jung, M.; Jin, H.S.; Kim, S.; Jang, J.; Oh, G.T.; et al. PPAR- $\alpha$ Activation Mediates Innate Host Defense through Induction of TFEB and Lipid Catabolism. J. Immunol. 2017, 198, 3283-3295. [CrossRef]

108. Mingione, A.; Cas, M.D.; Bonezzi, F.; Caretti, A.; Piccoli, M.; Anastasia, L.; Ghidoni, R.; Paroni, R.; Signorelli, P. Inhibition of Sphingolipid Synthesis as a Phenotype-Modifying Therapy in Cystic Fibrosis. Cell. Physiol. Biochem. 2020, 54, 110-125. [CrossRef]

109. Reddy, A.T.; Lakshmi, S.P.; Kleinhenz, J.M.; Sutliff, R.L.; Hart, C.M.; Reddy, R.C. Endothelial Cell Peroxisome ProliferatorActivated Receptor $\gamma$ Reduces Endotoxemic Pulmonary Inflammation and Injury. J. Immunol. 2012, 189, 5411-5420. [CrossRef]

110. Belvisi, M.G.; Hele, D.J. Peroxisome Proliferator-Activated Receptors as Novel Targets in Lung Disease*. Chest 2008, $134,152-157$. [CrossRef]

111. Belvisi, M.G.; Mitchell, J.A. Targeting PPAR receptors in the airway for the treatment of inflammatory lung disease. Br. J. Pharmacol. 2009, 158, 994-1003. [CrossRef] [PubMed]

112. Ferguson, H.E.; Thatcher, T.H.; Olsen, K.C.; Garcia-Bates, T.M.; Baglole, C.J.; Kottmann, R.M.; Strong, E.R.; Phipps, R.P.; Sime, P.J. Peroxisome proliferator-activated receptor-gamma ligands induce heme oxygenase- 1 in lung fibroblasts by a PPARgammaindependent, glutathione-dependent mechanism. Am. J. Physiol. Cell. Mol. Physiol. 2009, 297, L912-L919. [CrossRef]

113. Krönke, G.; Kadl, A.; Ikonomu, E.; Bluml, S.; Furnkranz, A.; Sarembock, I.J.; Bochkov, V.N.; Exner, M.; Binder, B.R.; Leitinger, N. Expression of Heme Oxygenase-1 in Human Vascular Cells Is Regulated by Peroxisome Proliferator-Activated Receptors. Arter. Thromb. Vasc. Biol. 2007, 27, 1276-1282. [CrossRef] [PubMed]

114. Zhang, D.; Wang, G.; Han, N.; Zhang, Y.; Xu, J.; Lu, J.; Li, S.; Xie, X.; Liu, L.; Dong, L.; et al. Activation of PPAR- $\gamma$ ameliorates pulmonary arterial hypertension via inducing heme oxygenase-1 and p21WAF1: An in vivo study in rats. Life Sci. 2014, 98, 39-43. [CrossRef] [PubMed]

115. Cho, R.-L.; Yang, C.-C.; Tseng, H.-C.; Hsiao, L.-D.; Lin, C.-C.; Yang, C.-M. Haem oxygenase-1 up-regulation by rosiglitazone via ROS-dependent Nrf2-antioxidant response elements axis or PPAR $\gamma$ attenuates LPS-mediated lung inflammation. Br. J. Pharmacol. 2018, 175, 3928-3946. [CrossRef] [PubMed]

116. Cho, R.-L.; Lin, W.-N.; Wang, C.-Y.; Yang, C.-C.; Hsiao, L.-D.; Lin, C.-C.; Yang, C.-M. Heme oxygenase-1 induction by rosiglitazone via $\mathrm{PKC} \alpha / \mathrm{AMPK} \alpha / \mathrm{p} 38 \mathrm{MAPK} \alpha / \mathrm{SIRT} 1 / \mathrm{PPAR} \gamma$ pathway suppresses lipopolysaccharide-mediated pulmonary inflammation. Biochem. Pharmacol. 2018, 148, 222-237. [CrossRef]

117. Yao, J.; Pan, D.; Zhao, Y.; Zhao, L.; Sun, J.; Wang, Y.; You, Q.-D.; Xi, T.; Guo, Q.-L.; Lu, N. Wogonin prevents lipopolysaccharideinduced acute lung injury and inflammation in mice via peroxisome proliferator-activated receptor gamma-mediated attenuation of the nuclear factor-kappaB pathway. Immunology 2014, 143, 241-257. [CrossRef]

118. Huang, H.; Cheng, Z.; Shi, H.; Xin, W.; Wang, T.T.Y.; Yu, L. (Lucy) Isolation and Characterization of Two Flavonoids, Engeletin and Astilbin, from the Leaves of Engelhardia roxburghiana and Their Potential Anti-inflammatory Properties. J. Agric. Food Chem. 2011, 59, 4562-4569. [CrossRef]

119. Jiang, X.; Chen, L.; Zhang, Z.; Sun, Y.; Wang, X.; Wei, J. Protective and Therapeutic Effects of Engeletin on LPS-Induced Acute Lung Injury. Inflammation 2018, 41, 1259-1265. [CrossRef]

120. Wang, Y.; Xu, Y.; Zhang, P.; Ruan, W.; Zhang, L.; Yuan, S.; Pang, T.; Jia, A.-Q. Smiglaside A ameliorates LPS-induced acute lung injury by modulating macrophage polarization via AMPK-PPAR $\gamma$ pathway. Biochem. Pharmacol. 2018, 156, 385-395. [CrossRef] 
121. Liao, Z.; Dong, J.; Wu, W.; Yang, T.; Wang, T.; Guo, L.; Chen, L.; Xu, D.; Wen, F.-Q. Resolvin D1 attenuates inflammation in lipopolysaccharide-induced acute lung injury through a process involving the PPAR $\gamma / \mathrm{NF}-\mathrm{\kappa B}$ pathway. Respir. Res. 2012, 13, 110. [CrossRef] [PubMed]

122. Volckaert, T.; Dill, E.; Campbell, A.; Tiozzo, C.; Majka, S.; Bellusci, S.; De Langhe, S. Parabronchial smooth muscle constitutes an airway epithelial stem cell niche in the mouse lung after injury. J. Clin. Investig. 2011, 121, 4409-4419. [CrossRef] [PubMed]

123. Zulueta, A.; Colombo, M.; Peli, V.; Falleni, M.; Tosi, D.; Ricciardi, M.; Baisi, A.; Bulfamante, G.; Chiaramonte, R.; Caretti, A. Lung mesenchymal stem cells-derived extracellular vesicles attenuate the inflammatory profile of Cystic Fibrosis epithelial cells. Cell. Signal. 2018, 51, 110-118. [CrossRef]

124. Heming, M.; Gran, S.; Jauch, S.-L.; Fischer-Riepe, L.; Russo, A.; Klotz, L.; Hermann, S.; Schafers, M.; Roth, J.; BarczykKahlert, K. Peroxisome Proliferator-Activated Receptor- $\gamma$ Modulates the Response of Macrophages to Lipopolysaccharide and Glucocorticoids. Front. Immunol. 2018, 9, 893. [CrossRef] [PubMed]

125. Di Paola, R.; Cuzzocrea, S. Peroxisome Proliferator-Activated Receptors and Acute Lung Injury. PPAR Res. 2007, $2007,1-8$. [CrossRef] [PubMed]

126. Aoki, Y.; Maeno, T.; Aoyagi, K.; Ueno, M.; Aoki, F.; Aoki, N.; Nakagawa, J.; Sando, Y.; Shimizu, Y.; Suga, T.; et al. Pioglitazone, a Peroxisome Proliferator-Activated Receptor Gamma Ligand, Suppresses Bleomycin-Induced Acute Lung Injury and Fibrosis. Respiration 2008, 77, 311-319. [CrossRef]

127. Ohta, A.; Sitkovsky, M. Role of G-protein-coupled adenosine receptors in downregulation of inflammation and protection from tissue damage. Nature 2001, 414, 916-920. [CrossRef]

128. Sharma, A.K.; Linden, J.; Kron, I.L.; Laubach, V.E. Protection from pulmonary ischemia-reperfusion injury by adenosine A2A receptor activation. Respir. Res. 2009, 10,1-9. [CrossRef]

129. He, X.; Hu, J.-L.; Li, J.; Zhao, L.; Zhang, Y.; Zeng, Y.-J.; Dai, S.-S.; He, F.-T. A feedback loop in PPAR $\gamma$-adenosine A2A receptor signaling inhibits inflammation and attenuates lung damages in a mouse model of LPS-induced acute lung injury. Cell. Signal. 2013, 25, 1913-1923. [CrossRef]

130. Shen, J.; Sakaida, I.; Uchida, K.; Terai, S.; Okita, K. Leptin enhances TNF- $\alpha$ production via p38 and JNK MAPK in LPS-stimulated Kupffer cells. Life Sci. 2005, 77, 1502-1515. [CrossRef]

131. Iikuni, N.; Lam, Q.L.K.; Lu, L.; Matarese, G.; La Cava, A. Leptin and Inflammation. Curr. Immunol. Rev. 2008, 4, 70-79. [CrossRef] [PubMed]

132. La Cava, A. Leptin in inflammation and autoimmunity. Cytokine 2017, 98, 51-58. [CrossRef] [PubMed]

133. Tschöp, J.; Nogueiras, R.; Lockie, S.H.; Kasten, K.R.; Castañeda, T.R.; Huber, N.; Guanciale, K.; Perez-Tilve, D.; Habegger, K.; Ottaway, N.; et al. CNS leptin action modulates immune response and survival in sepsis. J. Neurosci. 2010, 30, 6036-6047. [CrossRef]

134. Paz-Filho, G.; Mastronardi, C.A.; Franco, C.B.; Wang, K.B.; Wong, M.-L.; Licinio, J. Leptin: Molecular mechanisms, systemic pro-inflammatory effects, and clinical implications. Arq. Bras. Endocrinol. Metabol. 2012, 56, 597-607. [CrossRef] [PubMed]

135. Nair, P.; Radford, K.; Fanat, A.; Janssen, L.J.; Peters-Golden, M.; Cox, P.G. The Effects of Leptin on Airway Smooth Muscle Responses. Am. J. Respir. Cell Mol. Biol. 2008, 39, 475-481. [CrossRef]

136. Vernooy, J.H.; Ubags, N.D.; Brusselle, G.G.; Tavernier, J.; Suratt, B.T.; Joos, G.F.; Wouters, E.F.; Bracke, K. Leptin as regulator of pulmonary immune responses: Involvement in respiratory diseases. Pulm. Pharmacol. Ther. 2013, 26, 464-472. [CrossRef]

137. Assad, N.A.; Sood, A. Leptin, adiponectin and pulmonary diseases. Biochimie 2012, 94, 2180-2189. [CrossRef]

138. Abbasi, A.; Moghadam, A.A.; Kahrarian, Z.; Abbsavaran, R.; Yari, K.; Alizadeh, E. Molecular effects of leptin on peroxisome proliferator activated receptor gamma (PPAR- $\gamma$ ) mRNA expression in rat's adipose and liver tissue. Cell. Mol. Biol. 2017, 63, 89-93. [CrossRef]

139. Ajuwon, K.M.; Spurlock, M.E. Adiponectin inhibits LPS-induced NF-kB activation and IL-6 production and increases PPAR $\gamma 2$ expression in adipocytes. Am. J. Physiol. Integr. Comp. Physiol. 2005, 288, R1220-R1225. [CrossRef]

140. Wulster-Radcliffe, M.C.; Ajuwon, K.M.; Wang, J.; Christian, J.A.; Spurlock, M.E. Adiponectin differentially regulates cytokines in porcine macrophages. Biochem. Biophys. Res. Commun. 2004, 316, 924-929. [CrossRef]

141. Wolf, A.M.; Wolf, D.; Rumpold, H.; Enrich, B.; Tilg, H. Adiponectin induces the anti-inflammatory cytokines IL-10 and IL-1RA in human leukocytes. Biochem. Biophys. Res. Commun. 2004, 323, 630-635. [CrossRef] [PubMed]

142. Ishtiaq, S.M.; Rashid, H.; Hussain, Z.; Arshad, M.I.; Khan, J.A. Adiponectin and PPAR: A setup for intricate crosstalk between obesity and non-alcoholic fatty liver disease. Rev. Endocr. Metab. Disord. 2019, 20, 253-261. [CrossRef] [PubMed]

143. Deng, W.; Yang, J.; Lin, X.; Shin, J.; Gao, J.; Zhong, X.-P. Essential Role of mTORC1 in Self-Renewal of Murine Alveolar Macrophages. J. Immunol. 2016, 198, 492-504. [CrossRef] [PubMed]

144. Hussell, T.; Bell, T.J. Alveolar macrophages: Plasticity in a tissue-specific context. Nat. Rev. Immunol. 2014, 14, 81-93. [CrossRef]

145. Kawasaki, T.; Ito, K.; Miyata, H.; Akira, S.; Kawai, T. Deletion of PIK fyve alters alveolar macrophage populations and exacerbates allergic inflammation in mice. EMBO J. 2017, 36, 1707-1718. [CrossRef]

146. Kopf, M.; Schneider, C.; Nobs, S.P. The development and function of lung-resident macrophages and dendritic cells. Nat. Immunol. 2014, 16, 36-44. [CrossRef]

147. Cardani, A.; Boulton, A.; Kim, T.S.; Braciale, T.J. Alveolar Macrophages Prevent Lethal Influenza Pneumonia By Inhibiting Infection Of Type-1 Alveolar Epithelial Cells. PLoS Pathog. 2017, 13, e1006140. [CrossRef] 
148. Kim, H.M.; Lee, Y.-W.; Lee, K.-J.; Kim, H.S.; Cho, S.W.; Van Rooijen, N.; Guan, Y.; Seo, S.H. Alveolar Macrophages Are Indispensable for Controlling Influenza Viruses in Lungs of Pigs. J. Virol. 2008, 82, 4265-4274. [CrossRef]

149. Laidlaw, B.J.; Decman, V.; Ali, M.-A.A.; Abt, M.C.; Wolf, A.I.; Monticelli, L.A.; Mozdzanowska, K.; Angelosanto, J.M.; Artis, D.; Erikson, J.; et al. Cooperativity Between CD8+ T Cells, Non-Neutralizing Antibodies, and Alveolar Macrophages Is Important for Heterosubtypic Influenza Virus Immunity. PLoS Pathog. 2013, 9, e1003207. [CrossRef]

150. Purnama, C.; Ng, S.L.; Tetlak, P.; Setiagani, Y.A.; Kandasamy, M.; Baalasubramanian, S.; Karjalainen, K.; Ruedl, C. Transient ablation of alveolar macrophages leads to massive pathology of influenza infection without affecting cellular adaptive immunity. Eur. J. Immunol. 2014, 44, 2003-2012. [CrossRef]

151. Gautier, E.L.; Chow, A.; Spanbroek, R.; Marcelin, G.; Greter, M.; Jakubzick, C.; Bogunovic, M.; Leboeuf, M.; Van Rooijen, N.; Habenicht, A.J.R.; et al. Systemic analysis of PPAR $\gamma$ in mouse macrophage populations reveals marked diversity in expression with critical roles in resolution of inflammation and airway immunity. J. Immunol. 2012, 189, 2614-2624. [CrossRef] [PubMed]

152. Nathan, C.; Ding, A. Nonresolving Inflammation. Cell 2010, 140, 871-882. [CrossRef] [PubMed]

153. Mizgerd, J.P. Acute Lower Respiratory Tract Infection. New Engl. J. Med. 2008, 358, 716-727. [CrossRef]

154. Soehnlein, O.; Lindbom, L. Phagocyte partnership during the onset and resolution of inflammation. Nat. Rev. Immunol. 2010, 10, 427-439. [CrossRef]

155. Ray, N.B.; Durairaj, L.; Chen, B.B.; McVerry, B.J.; Ryan, A.J.; Donahoe, M.; Waltenbaugh, A.K.; O’Donnell, C.P.; Henderson, F.C.; Etscheidt, C.A.; et al. Dynamic regulation of cardiolipin by the lipid pump Atp8b1 determines the severity of lung injury in experimental pneumonia. Nat. Med. 2010, 16, 1120-1127. [CrossRef] [PubMed]

156. Chakraborty, K.; Raundhal, M.; Chen, B.B.; Morse, C.; Tyurina, Y.Y.; Khare, A.; Oriss, T.B.; Huff, R.; Lee, J.S.; Croix, C.M.S.; et al. The mito-DAMP cardiolipin blocks IL-10 production causing persistent inflammation during bacterial pneumonia. Nat. Commun. 2017, 8, 13944. [CrossRef]

157. Bedi, B.; Maurice, N.M.; Ciavatta, V.T.; Lynn, K.S.; Yuan, Z.; Molina, S.A.; Joo, M.; Tyor, W.R.; Goldberg, J.B.; Koval, M.; et al. Peroxisome proliferator-activated receptor- $\gamma$ agonists attenuate biofilm formation by Pseudomonas aeruginosa. FASEB J. 2017, 31, 3608-3621. [CrossRef]

158. Gonçalves-De-Albuquerque, C.F.; Silva, A.R.; Burth, P.; Rocco, P.R.M.; Castro-Faria, M.V.; Castro-Faria-Neto, H.C. Possible mechanisms of Pseudomonas aeruginosa-associated lung disease. Int. J. Med. Microbiol. 2016, 306, 20-28. [CrossRef]

159. Guirado, E.; Rajaram, M.V.S.; Chawla, A.; Daigle, J.; La Perle, K.M.D.; Arnett, E.; Turner, J.; Schlesinger, L.S. Deletion of PPAR $\gamma$ in lung macrophages provides an immunoprotective response against M. tuberculosis infection in mice. Tuberculosis 2018, 111, 170-177. [CrossRef]

160. Malur, A.; Mohan, A.; Barrington, R.A.; Leffler, N.; Malur, A.; Muller-Borer, B.; Murray, G.; Kew, K.; Zhou, C.; Russell, J.; et al. Peroxisome Proliferator-activated Receptor- $\gamma$ Deficiency Exacerbates Fibrotic Response to Mycobacteria Peptide in Murine Sarcoidosis Model. Am. J. Respir. Cell Mol. Biol. 2019, 61, 198-208. [CrossRef]

161. Gonçalves-De-Albuquerque, C.F.; Rohwedder, I.; Silva, A.R.; Ferreira, A.S.; Kurz, A.R.M.; Cougoule, C.; Klapproth, S.; Eggersmann, T.; Silva, J.D.; De Oliveira, G.P.; et al. The Yin and Yang of Tyrosine Kinase Inhibition During Experimental Polymicrobial Sepsis. Front. Immunol. 2018, 9, 901. [CrossRef] [PubMed]

162. Kaplan, J.M.; Nowell, M.; Chima, R.; Zingarelli, B. Pioglitazone reduces inflammation through inhibition of NF- $к B$ in polymicrobial sepsis. Innate Immun. 2013, 20, 519-528. [CrossRef] [PubMed]

163. Kaplan, J.M.; Hake, P.W.; Denenberg, A.; Nowell, M.; Piraino, G.; Zingarelli, B. Phosphorylation of Extracellular Signal-Regulated Kinase (ERK)-1/2 Is Associated with the Downregulation of Peroxisome Proliferator-Activated Receptor (PPAR)- $\gamma$ during Polymicrobial Sepsis. Mol. Med. 2010, 16, 491-497. [CrossRef] [PubMed]

164. Li, J.; Pritchard, D.K.; Wang, X.; Park, D.R.; Bumgarner, R.E.; Schwartz, S.M.; Liles, W.C. cDNA microarray analysis reveals fundamental differences in the expression profiles of primary human monocytes, monocyte-derived macrophages, and alveolar macrophages. J. Leukoc. Biol. 2006, 81, 328-335. [CrossRef]

165. Chen, Q.; Zhang, K.; Jin, Y.; Zhu, T.; Cheng, B.; Shu, Q.; Fang, X.-M. Triggering Receptor Expressed on Myeloid Cells-2 Protects against Polymicrobial Sepsis by Enhancing Bacterial Clearance. Am. J. Respir. Crit. Care Med. 2013, 188, 201-212. [CrossRef]

166. Sharif, O.; Gawish, R.; Warszawska, J.M.; Martins, R.; Lakovits, K.; Hladik, A.; Doninger, B.; Brunner, J.S.; Korosec, A.; Schwarzenbacher, R.E.; et al. The Triggering Receptor Expressed on Myeloid Cells 2 Inhibits Complement Component 1q Effector Mechanisms and Exerts Detrimental Effects during Pneumococcal Pneumonia. PLoS Pathog. 2014, 10, e1004167. [CrossRef]

167. Moseley, C.E.; Webster, R.G.; Aldridge, J.R. Original Article: Peroxisome proliferator-activated receptor and AMP-activated protein kinase agonists protect against lethal influenza virus challenge in mice. Influ. Other Respir. Viruses 2010, 4, 307-311. [CrossRef]

168. Darwish, I.; Mubareka, S.; Liles, W.C. Immunomodulatory therapy for severe influenza. Expert Rev. Anti-Infect. Ther. 2011, 9 , 807-822. [CrossRef]

169. Cloutier, A.; Marois, I.; Cloutier, D.; Verreault, C.; Cantin, A.M.; Richter, M.V. The Prostanoid 15-Deoxy- $\Delta 12,14-P r o s t a g l a n d i n-J 2$ Reduces Lung Inflammation and Protects Mice Against Lethal Influenza Infection. J. Infect. Dis. 2012, 205, 621-630. [CrossRef]

170. Fedson, D.S. Treating influenza with statins and other immunomodulatory agents. Antivir. Res. 2013, 99, 417-435. [CrossRef]

171. Bassaganya-Riera, J.; Guri, A.J.; Lu, P.; Climent, M.; Carbo, A.; Sobral, B.W.; Horne, W.T.; Lewis, S.N.; Bevan, D.; Hontecillas, R. Abscisic Acid Regulates Inflammation via Ligand-binding Domain-independent Activation of Peroxisome Proliferator-activated Receptor $\gamma$. J. Biol. Chem. 2010, 286, 2504-2516. [CrossRef] [PubMed] 
172. Guri, A.J.; Misyak, S.A.; Hontecillas, R.; Hasty, A.H.; Liu, D.; Si, H.; Bassaganya-Riera, J. Abscisic acid ameliorates atherosclerosis by suppressing macrophage and CD4+ T cell recruitment into the aortic wall. J. Nutr. Biochem. 2010, 21, 1178-1185. [CrossRef] [PubMed]

173. Hontecillas, R.; Roberts, P.C.; Carbo, A.; Vives, C.; Horne, W.T.; Genis, S.; Velayudhan, B.; Bassaganya-Riera, J. Dietary abscisic acid ameliorates influenza-virus-associated disease and pulmonary immunopathology through a PPAR $\gamma$-dependent mechanism. J. Nutr. Biochem. 2012, 24, 1019-1027. [CrossRef] [PubMed]

174. Huang, S.; Zhu, B.; Cheon, I.S.; Goplen, N.P.; Jiang, L.; Zhang, R.; Peebles, R.S.; Mack, M.; Kaplan, M.H.; Limper, A.H.; et al. PPAR $-\gamma$ in Macrophages Limits Pulmonary Inflammation and Promotes Host Recovery following Respiratory Viral Infection. J. Virol. 2019, 93, 1-15. [CrossRef] [PubMed]

175. Huang, S.; Jiang, L.; Cheon, I.S.; Sun, J. Targeting Peroxisome Proliferator-Activated Receptor-Gamma Decreases Host Mortality After Influenza Infection in Obese Mice. Viral Immunol. 2019, 32, 161-169. [CrossRef] [PubMed]

176. Zhang, W.; Xu, Y.-Z.; Liu, B.; Wu, R.; Yang, Y.-Y.; Xiao, X.-Q.; Zhang, X. Pioglitazone Upregulates Angiotensin Converting Enzyme 2 Expression in Insulin-Sensitive Tissues in Rats with High-Fat Diet-Induced Nonalcoholic Steatohepatitis. Sci. World J. 2014, 2014, 1-7. [CrossRef] [PubMed]

177. Sánchez-Aguilar, M.; Ibarra-Lara, L.; Mondragón, L.D.V.; Rubio-Ruiz, M.E.; Aguilar-Navarro, A.G.; Zamorano-Carrillo, A.; Ramírez-Ortega, M.D.C.; Pastelín-Hernández, G.; Sánchez-Mendoza, A. Rosiglitazone, a Ligand to PPAR $\gamma$, Improves Blood Pressure and Vascular Function through Renin-Angiotensin System Regulation. PPAR Res. 2019, 2019, 1-12. [CrossRef] [PubMed]

178. Filardi, T.; Morano, S. COVID-19: Is there a link between the course of infection and pharmacological agents in diabetes? J. Endocrinol. Investig. 2020, 43, 1053-1060. [CrossRef]

179. Ghoneim, H.E.; Thomas, P.G.; McCullers, J.A. Depletion of alveolar macrophages during influenza infection facilitates bacterial superinfections. J. Immunol. 2013, 191, 1250-1259. [CrossRef]

180. Nakamura, S.; Davis, K.M.; Weiser, J.N. Synergistic stimulation of type I interferons during influenza virus coinfection promotes Streptococcus pneumoniae colonization in mice. J. Clin. Investig. 2011, 121, 3657-3665. [CrossRef]

181. Moorthy, A.N.; Narasaraju, T.; Rai, P.; Perumalsamy, R.; Tan, K.B.; Wang, S.; Engelward, B.P.; Chow, V.T.K. In vivo and in vitro studies on the roles of neutrophil extracellular traps during secondary pneumococcal pneumonia after primary pulmonary influenza infection. Front. Immunol. 2013, 4, 56. [CrossRef]

182. Small, C.-L.; Shaler, C.R.; McCormick, S.; Jeyanathan, M.; Damjanovic, D.; Brown, E.G.; Arck, P.C.; Jordana, M.; Kaushic, C.; Ashkar, A.A.; et al. Influenza Infection Leads to Increased Susceptibility to Subsequent Bacterial Superinfection by Impairing NK Cell Responses in the Lung. J. Immunol. 2010, 184, 2048-2056. [CrossRef] [PubMed]

183. Finelli, L.; Fiore, A.; Dhara, R.; Brammer, L.; Shay, D.K.; Kamimoto, L.; Fry, A.; Hageman, J.; Gorwitz, R.; Bresee, J.; et al. Influenza-Associated Pediatric Mortality in the United States: Increase of Staphylococcus aureus Coinfection. Pediatrics 2008, 122, 805-811. [CrossRef] [PubMed]

184. Rubinstein, E.; Kollef, M.H.; Nathwani, D. Pneumonia Caused by Methicillin-ResistantStaphylococcus aureus. Clin. Infect. Dis. 2008, 46, S378-S385. [CrossRef]

185. Sharma, R.; Kaundal, R.; Sharma, S.S. Amelioration of pulmonary dysfunction and neutrophilic inflammation by PPAR $\gamma$ agonist in LPS-exposed guinea pigs. Pulm. Pharmacol. Ther. 2009, 22, 183-189. [CrossRef]

186. Gopal, R.; Mendy, A.; Marinelli, M.A.; Richwalls, L.J.; Seger, P.J.; Patel, S.; McHugh, K.J.; Rich, H.E.; Grousd, J.A.; Forno, E.; et al. Peroxisome Proliferator-Activated Receptor Gamma (PPAR $\gamma$ ) Suppresses Inflammation and Bacterial Clearance during Influenza-Bacterial Super-Infection. Viruses 2019, 11, 505. [CrossRef]

187. Botta, M.; Audano, M.; Yaribeygi, H.; Sirtori, C.R.; Mitro, N.; Ruscica, M. PPAR Agonists and Metabolic Syndrome: An Established Role? Int. J. Mol. Sci. 2018, 19, 1197. [CrossRef]

188. Rousselot, P.; Prost, S.; Guilhot, J.; Roy, L.; Etienne, G.; Legros, L.; Charbonnier, A.; Coiteux, V.; Cony-Makhoul, P.; Huguet, F.; et al. Pioglitazone together with imatinib in chronic myeloid leukemia: A proof of concept study. Cancer 2016, 123, 1791-1799. [CrossRef]

189. Kumar, B.R.P.; Kumar, A.P.; Jose, J.A.; Prabitha, P.; Yuvaraj, S.; Sandhya, C.; Jeyarani, V.; Manisha, C.; Banerjee, S.; Jeyabalan, J.B.; et al. Minutes of PPAR- $\gamma$ Agonism and Neuroprotection. Neurochem. Int. 2020, 140, 104814. [CrossRef]

190. Anderson, J.R.; Mortimer, K.; Pang, L.; Smith, K.M.; Bailey, H.; Hodgson, D.B.; Shaw, D.E.; Knox, A.; Harrison, T.W. Evaluation of the PPAR- $\gamma$ Agonist Pioglitazone in Mild Asthma: A Double-Blind Randomized Controlled Trial. PLoS ONE 2016, 11, e0160257. [CrossRef]

191. Reddy, A.T.; Lakshmi, S.P.; Reddy, R.C. PPAR $\gamma$ in Bacterial Infections: A Friend or Foe? PPAR Res. 2016, 2016, 1-7. [CrossRef]

192. Devchand, P.R.; Liu, T.; Altman, R.B.; Fitzgerald, G.A.; Schadt, E.E. The Pioglitazone Trek via Human PPAR Gamma: From Discovery to a Medicine at the FDA and Beyond. Front. Pharmacol. 2018, 9, 1093. [CrossRef] [PubMed] 